\title{
Nutrient budgets for the South China Sea basin
}

\author{
Chen-Tung Arthur Chen ${ }^{a, *}$, Shu-Lun Wang ${ }^{\text {b,1 }}$, Bing-Jye Wang ${ }^{a, 2}$, Su-Cheng Pai ${ }^{\text {c,3 }}$ \\ ${ }^{a}$ Institute of Marine Geology and Chemistry, National Sun Yat-sen University, Kaohsiung 804, Taiwan, ROC \\ ${ }^{\mathrm{b}}$ Department of Marine Environmental Engineering, National Kaohsiung Institute of Marine Technology, Kaohsiung 811, Taiwan, ROC \\ ${ }^{\mathrm{c}}$ Institute of Oceanography, National Taiwan University, Taipei, Taiwan, ROC
}

Received 8 July 1999; received in revised form 23 April 2001; accepted 24 April 2001

\begin{abstract}
Varying atmospheric forcing and an elaborate geography make for a complex flow in the South China Sea (SCS). Throughout the year, the surface waters of the Kuroshio flow into the SCS, while the surface waters of the SCS flow out through the Bashi Channel. Cumulatively, there is a small ( $\sim 1 \mathrm{~Sv})$ net outflow of surface water (0-350-m depth) from the SCS in the wet season, but a net inflow $(\sim 3 \mathrm{~Sv})$ in the dry season through the Bashi Channel. The differences are mainly made up by inflow and outflow of Sunda Shelf Water in the wet and dry seasons, respectively.

Seawater, phosphorus, nitrogen and silicate budgets were calculated based on a box model. The results point out an intermediate water outflow (350-1350-m depth) into the West Philippine Sea (WPS) through the Bashi Channel in both the wet and dry seasons, though this, along with the nutrients it carries, is slightly larger in the dry season ( $2 \mathrm{~Sv})$ than in the wet $(1.8 \mathrm{~Sv})$. More importantly, the export of nutrient-laden SCS intermediate water through the Bashi Channel subsequently upwells onto the East China Sea (ECS) shelf. The denitrification rate for shelves in the SCS is $0.11 \mathrm{~mol} \mathrm{~N} \mathrm{~m}^{-2}$ year $^{-1}$, calculated by balancing the nitrogen budget. The oxygen consumption and the nutrient regeneration rates, based on the mass-balance and the one-dimensional advection-diffusion models, stand between those for the Bering Sea and the Sea of Japan. (C) 2001 Elsevier Science B.V. All rights reserved.
\end{abstract}

Keywords: South China Sea; East China Sea; Nutrient budgets; Flux; Denitrification; Upwelling

\section{Introduction}

The South China Sea (SCS) is the largest marginal sea in the world with an area of $3.5 \times 10^{6} \mathrm{~km}^{2}$ and

\footnotetext{
* Corresponding author. Tel.: +886-7-525-5146; fax: +886-7525-5346.

E-mail addresses: ctchen@mail.nsysu.edu.tw (C.-T.A. Chen), slwang@mail.nkimt.edu.tw (S.-L. Wang), scpai@ccms.ntu.edu.tw (S.-C. Pai).

${ }^{1}$ Fax: +886-7-364-5672.

${ }^{2}$ Fax: $+886-7-525-5346$.

${ }^{3}$ Fax: $+886-2-2362-7358$.
}

an average depth of about $1350 \mathrm{~m}$. The southern and southwestern regions comprise the shallow Sunda Shelf and the Gulf of Thailand, with an average depth of $50 \mathrm{~m}$. Although the Sunda Shelf connects to the Indian Ocean through the Strait of Malacca, the major passage is to the Java Sea through the even shallower Karimata and Gelasa Straits. The northern and northwestern regions are wide shelves leading to the East China Sea (ECS) through the 50-m deep Taiwan Strait. The central and northeastern parts of the SCS are rather deep, at over $5500 \mathrm{~m}$ in some places. The only deep connections from any part of the SCS to the outside are the 400-m deep Mindoro 
Strait, which leads to the Sulu Sea, and the 2200-m deep Bashi Channel, which opens to the Philippine Sea. The seasonally reversing monsoon winds play an important role in determining the upper ocean circulation, but the combination of such variable atmospheric forcing and the complex geometry contributes to the complicated dynamics of the flow in the SCS.

One example illustrates the complexity of the system. In November 1990, based on the Acoustic Doppler Current Profiler data, Chen (1995) observed a westward inflow of Kuroshio water above $400 \mathrm{~m}$ in the northern Bashi Channel, but an eastward outflow in the central Bashi Channel. A month later, based on geostrophic calculations, Liu et al. (1996) reported an outflow in the northern Bashi Channel above $1000 \mathrm{~m}$ and an inflow in the central and southern Channel. Even more complicated in the SCS are the nutrient dynamics, which have been poorly studied and are, therefore, little understood. These are very much subject to flow patterns within the area. Previous flux studies have often given a net flow in or out of the Bashi Channel (e.g. Wyrtki, 1961). However, the surface Kuroshio water that flows into the SCS is salty, but relatively nutrient poor, and what raised questions is that the surface water that flows out of the SCS is relatively fresh, but slightly nutrient rich. A net seawater flux is not at all informative in itself as it may actually be on the opposite direction of the salt and nutrient fluxes. It is clear that both the inward and outward fluxes through the Bashi Channel must be investigated.

Further, the SCS is a major fishing ground, with the fishing industry providing the livelihood of millions of fishermen in the surrounding territories. Like the ECS, the SCS receives large amounts of nutrients in the form of river discharge to support productivity. But it has been pointed out (Chen, 1996) that even with two of the largest rivers in the world, namely the Changjiang (Yangtze River) and the Hunghe (Yellow River), the ECS receives only a small portion of its nutrient input from rivers. Instead, upwelling is the major source of nutrients (Chen et al., 1995). The SCS also experiences intensive upwelling (Chen and Huang, 1995; Chao et al., 1996), but the share of its contribution to the euphotic zone compared with that of river discharge has not been determined. We have taken several cruises aboard the $\mathrm{R} / \mathrm{V}$ Ocean Researcher 1 in the SCS and, in particular, near the Bashi Channel. Here, we report data from two cruises and preliminary seawater and nutrient budgets based on a box model. The rates of oxygen consumption and nutrient regeneration were calculated based on the mass-balance and one-dimensional advection-diffusion models.

\section{Sampling locations and methods}

As part of the World Ocean Circulation Experiment (WOCE), data were collected on board R/V Ocean Researcher 1 (OR). OR cruise No. 462 covered the Pacific Repeated Section 20 (PR 20, across $21^{\circ} 45^{\prime} \mathrm{N}$ from below the southern tip of Taiwan to $\left.130^{\circ} \mathrm{E}\right)$ in September 1996. Fig. 1 shows a segment of the section covered near the Bashi Channel. The OR cruise No. 508 traversed a greater portion of the SCS in November 1997, as part of the South China Sea Monsoon Experiment (SCSMEX). The locations of the sampling stations are shown in Fig. 1. The shipboard temperature and salinity were determined with an SBE 911 plus CTD Conductivity-Temperature-Depth/Pressure (CTD) unit manufactured by Sea-Bird. Discrete samples were collected at various depths with a Rosette sampler fitted with 2.5-1 Niskin bottles and mounted on the Sea-Bird CTD unit for the determination of salinity, dissolved oxygen, nitrite, nitrate, phosphate and silicate. Data from the sensors of the CTD units were obtained during both the downcast and upcast. Discrete water samples were picked up during the upcast. The CTD unit was lowered and raised at a rate of about $1.0 \mathrm{~m} / \mathrm{s}$

Salinity $(S)$ in the discrete samples was determined by measuring conductivity with an AUTOSAL salinometer, which was calibrated with IAPSO standard seawater (batch No. P128). The precision of the measurements was 0.003 . The data from the AUTOSAL were used to check salinity of the CTD. Dissolved oxygen in the discrete samples was measured by direct spectrophotometry (Pai et al., 1993), with a precision of about $0.32 \%$ at the 190 $\mu \mathrm{mol} \mathrm{kg}{ }^{-1}$ level. Nitrate $\left(\mathrm{NO}_{3}^{-1}\right)$ plus nitrite $\left(\mathrm{NO}_{2}^{-1}\right)$ was measured by reducing nitrate to nitrite, and then identifying nitrite by means of the pink azo dye method (Strickland and Parsons, 1972) using a flow 


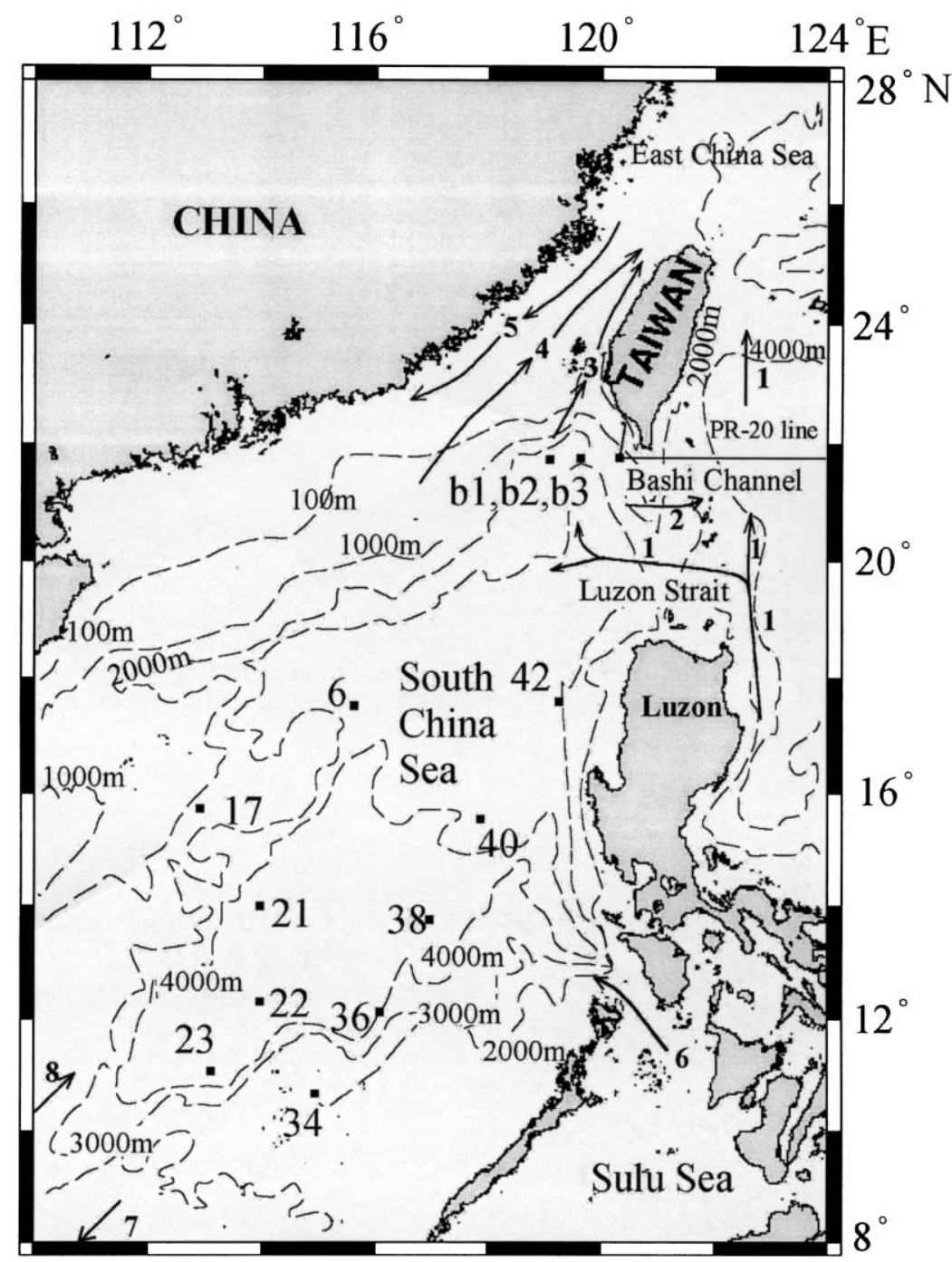

Fig. 1. OR 508 station locations and the WOCE PR 20 line. Arrows indicate, schematically, major surface currents [(1) Kuroshio; (2) outflowing SCS surface water; (3) Kuroshio branch; (4) outflowing SCS surface water; (5) incoming China coastal current in winter; (6) incoming Sulu Sea water through the Mindoro Strait; (7) outflowing SCS surface water in winter and; (8) incoming Sunda Shelf Water].

injection analyzer with an on-line $\mathrm{Cd}$ coil. The precision of this method was about $1 \%$ at $35 \mu \mathrm{mol} \mathrm{kg}{ }^{-1}$, and $3 \%$ at $1 \mu \mathrm{mol} \mathrm{kg}{ }^{-1}$. Nitrite $\left(\mathrm{NO}_{2}^{-1}\right)$ was determined from the pink azo dye method (Strickland and Parsons, 1972; Pai et al., 1990a) using a flow injection analyzer for a precision of $0.02 \mu \mathrm{mol} \mathrm{kg} \mathrm{kg}^{-1}$. Phosphate $\left(\mathrm{PO}_{4}^{-3}\right)$ was studied under the molybdenum blue method (Murphy and Riley, 1962; Pai et al., 1990b) using a flow injection analyzer. The precision of the measurements was about $0.5 \%$ at 2.8 $\mu \mathrm{mol} \mathrm{kg} \mathrm{kg}^{-1}$ and $3 \%$ at $0.1 \mu \mathrm{mol} \mathrm{kg} \mathrm{kg}^{-1}$. Silicate $\left(\mathrm{SiO}_{2}\right)$ was measured with the silicomolybdenum blue method (Fanning and Pilson, 1973) using a flow injection analyzer. The precision of the method was about $0.6 \%$ at $150 \mu \mathrm{mol} \mathrm{kg}{ }^{-1}$ and $2 \%$ at $5 \mu \mathrm{mol}$ $\mathrm{kg}^{-1}$. 

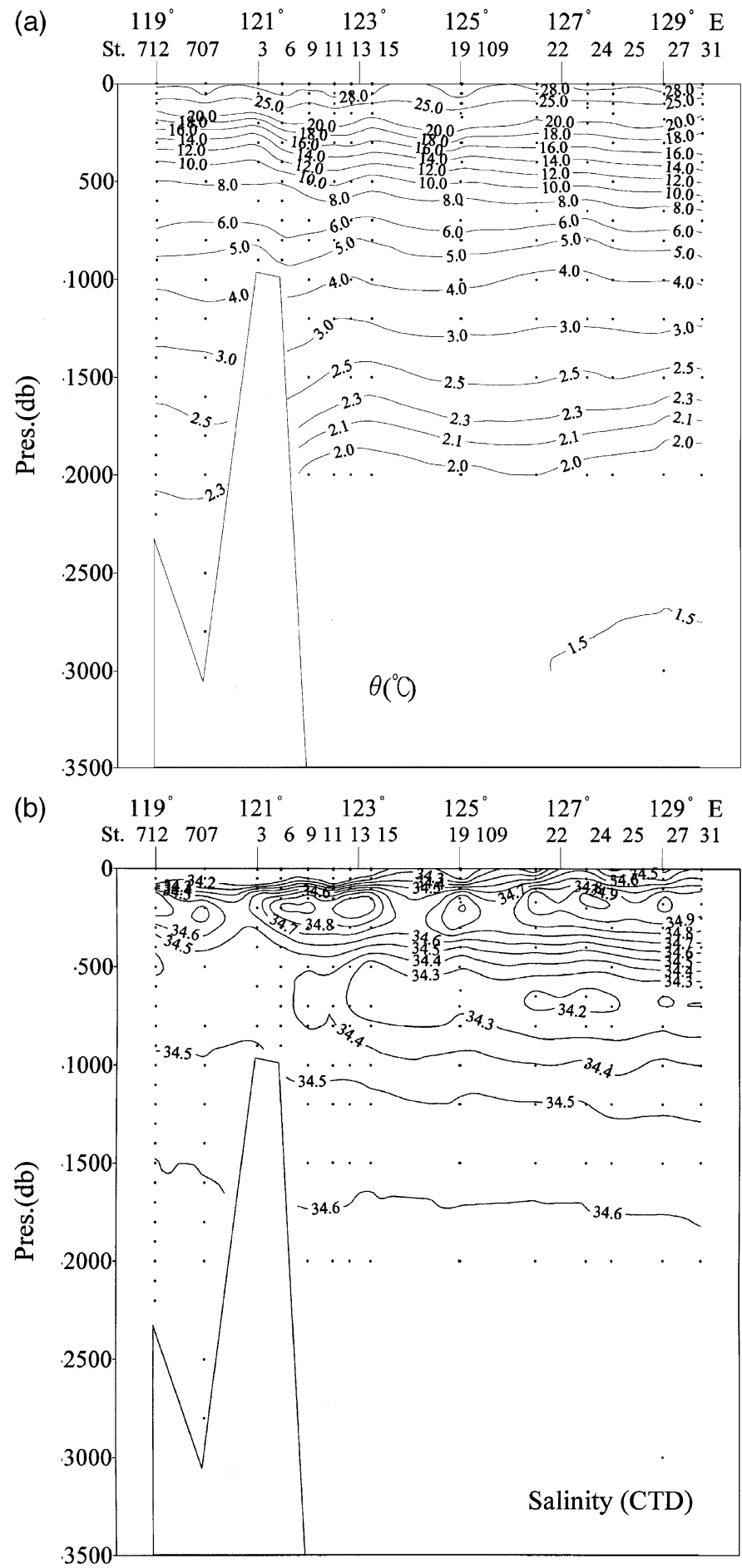

Fig. 2. Cross-sections of (a) $\theta$, (b) $S$, (c) $\mathrm{AOU}$, (d) $\mathrm{PO}_{4}^{3-}$, (e) $\mathrm{NO}_{3}^{-}$and (f) $\mathrm{SiO}_{2}$ for OR 462 . 

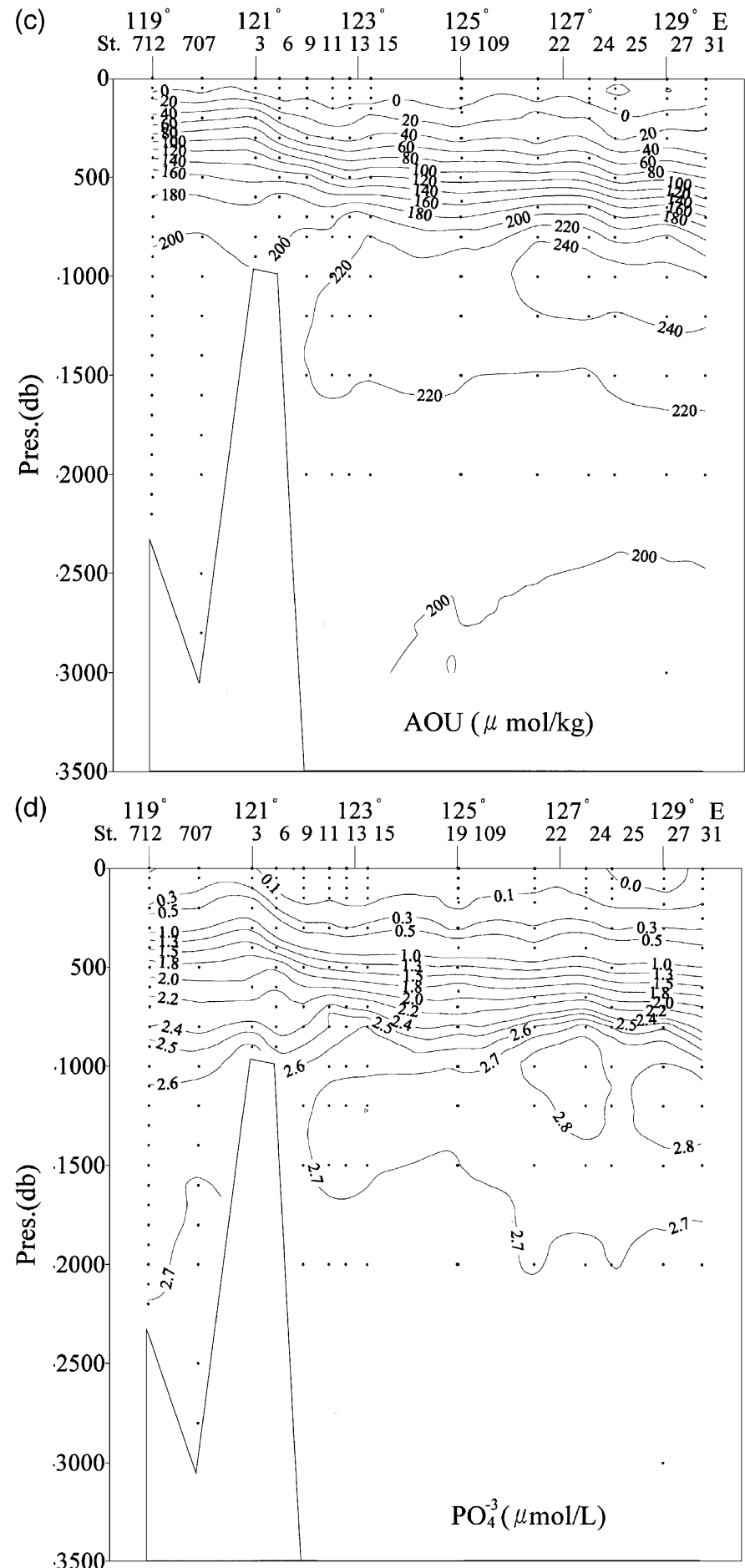

Fig. 2 (continued). 


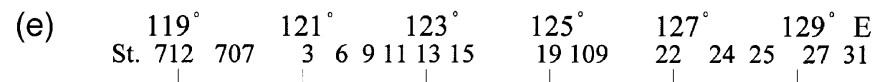

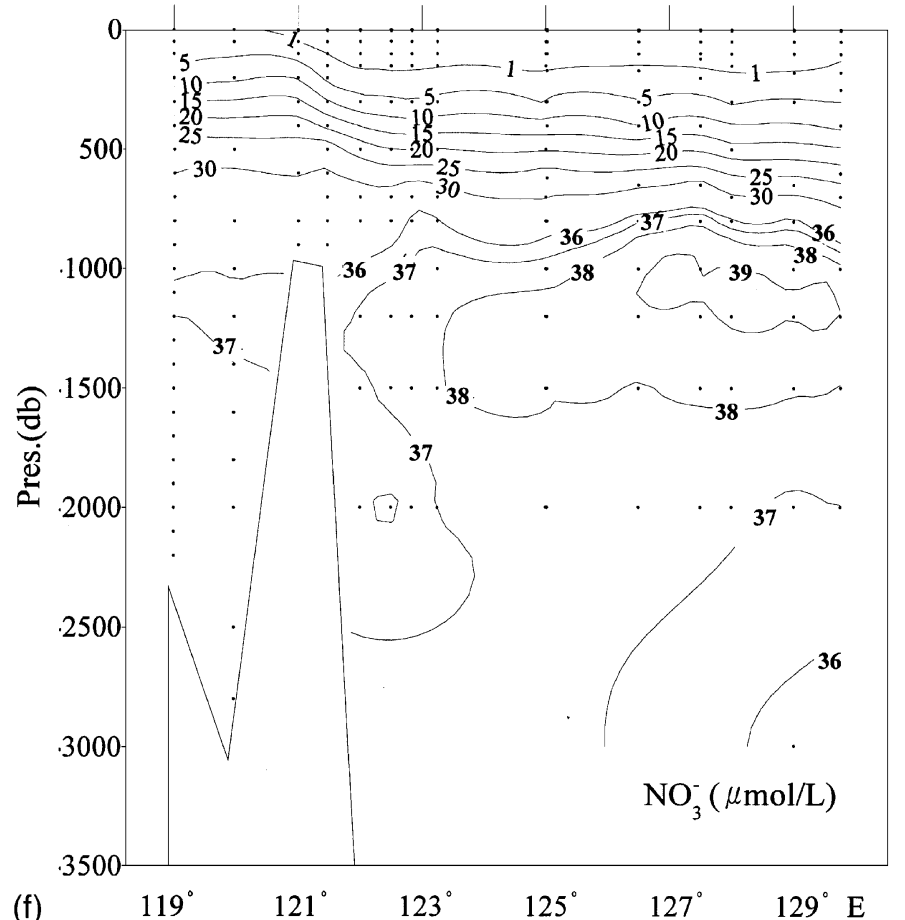

(f)
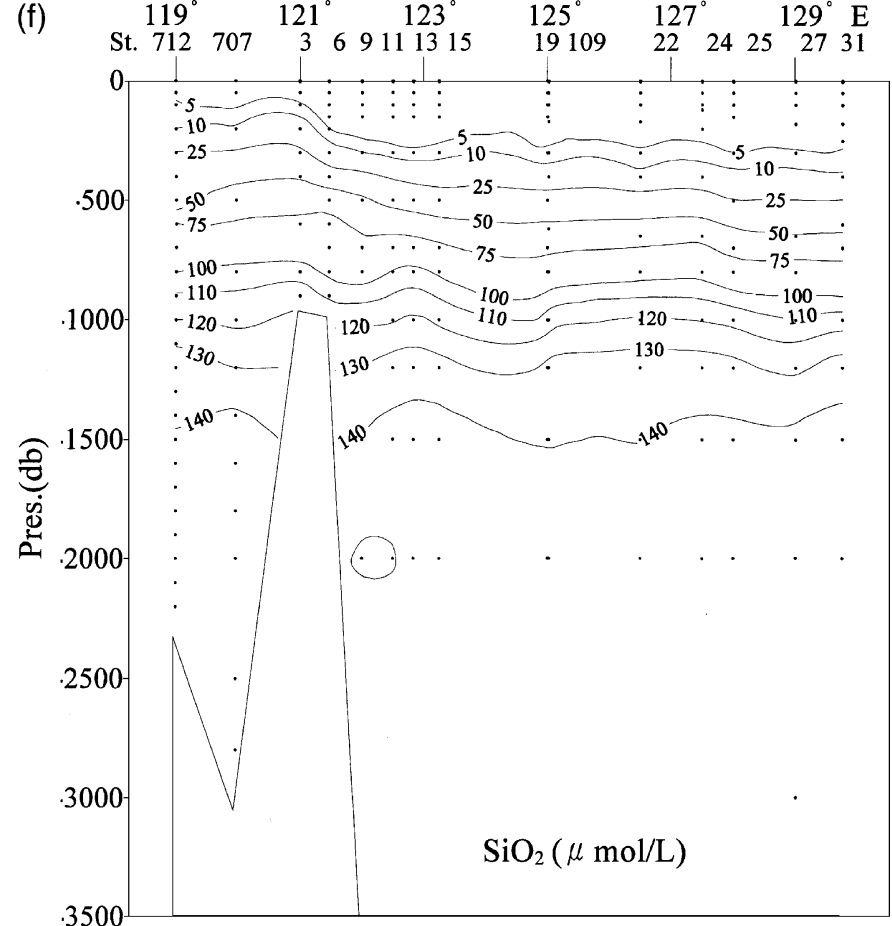

Fig. 2 (continued). 


\section{Description of results}

In Fig. 2, the vertical distribution of the West Philippine Sea (WPS) water is characterized by extremes in salinity. A shallow salinity maximum $(S>$ $35.0)$ is centered at approximately $150 \mathrm{~m}$ at $21^{\circ} 45^{\prime} \mathrm{N}$, $130^{\circ} \mathrm{E}$. The maximum salinity layer clearly extends to the SCS, but the salinity is reduced to below 34.8 at $21^{\circ} 45^{\prime} \mathrm{N}, 119^{\circ} \mathrm{E}$ in the SCS (Fig. 2). A pronounced minimum salinity core (the North Pacific Intermediate Water, $S<34.2$ ) at about $600 \mathrm{~m}$ in the WPS extends to a lesser degree across the Bashi Channel into the SCS and shoals to about $500 \mathrm{~m}$, while the minimum salinity increases to above 34.4. The corresponding east-west temperature contours also shoal toward the west. Intensive upwelling and vertical mixing tend to reduce the extreme signals in the SCS; thus, making both salinity extremes less pronounced (Fig. 2).

Chen and Huang (1996) and Chen and Wang (1998) reported that a mid-depth boundary between 350 and $1350 \mathrm{~m}$ encompassing the $S_{\min }$ layer seems to exist near $122^{\circ} \mathrm{E}$ above the continental slope near the Bashi Channel. To the east of it, the water mass belongs to the WPS, whereas to the west, it is mainly SCS water. The $S=34.4$ contour does not extend to the interior of the SCS. In terms of chemical parameters, the most striking difference between the SCS and WPS is that the apparent oxygen utilization (AOU, based on the oxygen solubility equation of Chen, 1981), nitrate and phosphate all show a maximum at about $1200 \mathrm{~m}$ in the WPS (Fig. 2). This is typical in many open oceans. Yet, the maximum is not as apparent in the SCS (Gong et al., 1992; Chen and Huang, 1995, 1996; Chen and Wang, 1998). This intermediate water at $1200 \mathrm{~m}$ in the WPS does flow into the SCS, but not to any great extent. Observational data (Chen and Huang, 1996) and model calculations (Chao et al., 1996) have shown that SCS Intermediate Water, defined by Chen and Huang (1996) as between 350 and $1350 \mathrm{~m}$, and by Chao et al. (1996) as between 600 and $1200 \mathrm{~m}$, also flows out of the SCS year-round. That the intermediate water in the WPS flows into the SCS cannot be ignored, if it did not, there would be no salinity minimum, however weak, nor maximum in other chemical properties at all. What is important to note, however, is that outflow far surpasses inflow.
Previous studies (Wang, 1986; Liu and Liu, 1988; Chao et al., 1996) consistently point out that the SCS deep and bottom waters originate in the WPS yearround, and intensive upwelling and vertical mixing occur in the SCS. The Luzon Strait, with the deepest sill at $2200 \mathrm{~m}$, forms the only deep connection between the WPS and the SCS, thus the physical and chemical properties remain essentially constant below $2200 \mathrm{~m}$ in the SCS. It is to be noted that because of the low dissolution rate of siliceous shells, silicate does not show a maximum in either the SCS or the WPS, and the concentration increases steadily with depth. The rate of increase is high above $1500 \mathrm{~m}$, but very much reduced below. Of significance, for waters above $1000 \mathrm{~m}$, the nutrient contours all shoal westwardly from the WPS to the SCS.

Chen and Huang (1995) reported that the SCS flushes rather quickly, on the order of 40 years, which means the intermediate, deep and bottom waters are essentially the same age. Because of the short residence time, the amount of particulate matter decomposition in the water column is sufficient to produce only a small maximum of chemical properties in the vertical profiles. These profiles look more like the Atlantic instead of like the Pacific, where deep waters are much older than that in the Atlantic. Waters in the SCS proper can be said to be relatively uniform, especially those below 2000 m. Fig. 3a-f shows the north-south cross-sections of $\theta, S, \mathrm{AOU}$, nitrate, phosphate and silicate in the eastern part of the SCS basin. The potential temperature is above $2.1{ }^{\circ} \mathrm{C}$ even at $4000 \mathrm{~m}$, and this is almost $0.8{ }^{\circ} \mathrm{C}$ warmer than in the WPS at the same depth. The salinity is also quite uniform at about $34.6 \pm 0.1$ below $1000 \mathrm{~m}$. However, there is a weak salinity minimum layer at about $500 \mathrm{~m}$ with a weak salinity maximum above it. These signatures, albeit weak, can be traced to their sources in the WPS. At stations south of $20^{\circ} \mathrm{N}$, a thin layer of fresher water with salinity below 33.05 lies near the surface. This lowsalinity water clearly has its origin in the southern SCS.

Fig. 3c shows the north-south cross-section of AOU in the eastern SCS basin. All waters deeper than about $2000 \mathrm{~m}$ originate in the 2000-m deep WPS water outside the Bashi Channel. The incoming waters sink, spread out, upwell, turn around and finally flow out of the SCS as intermediate water 

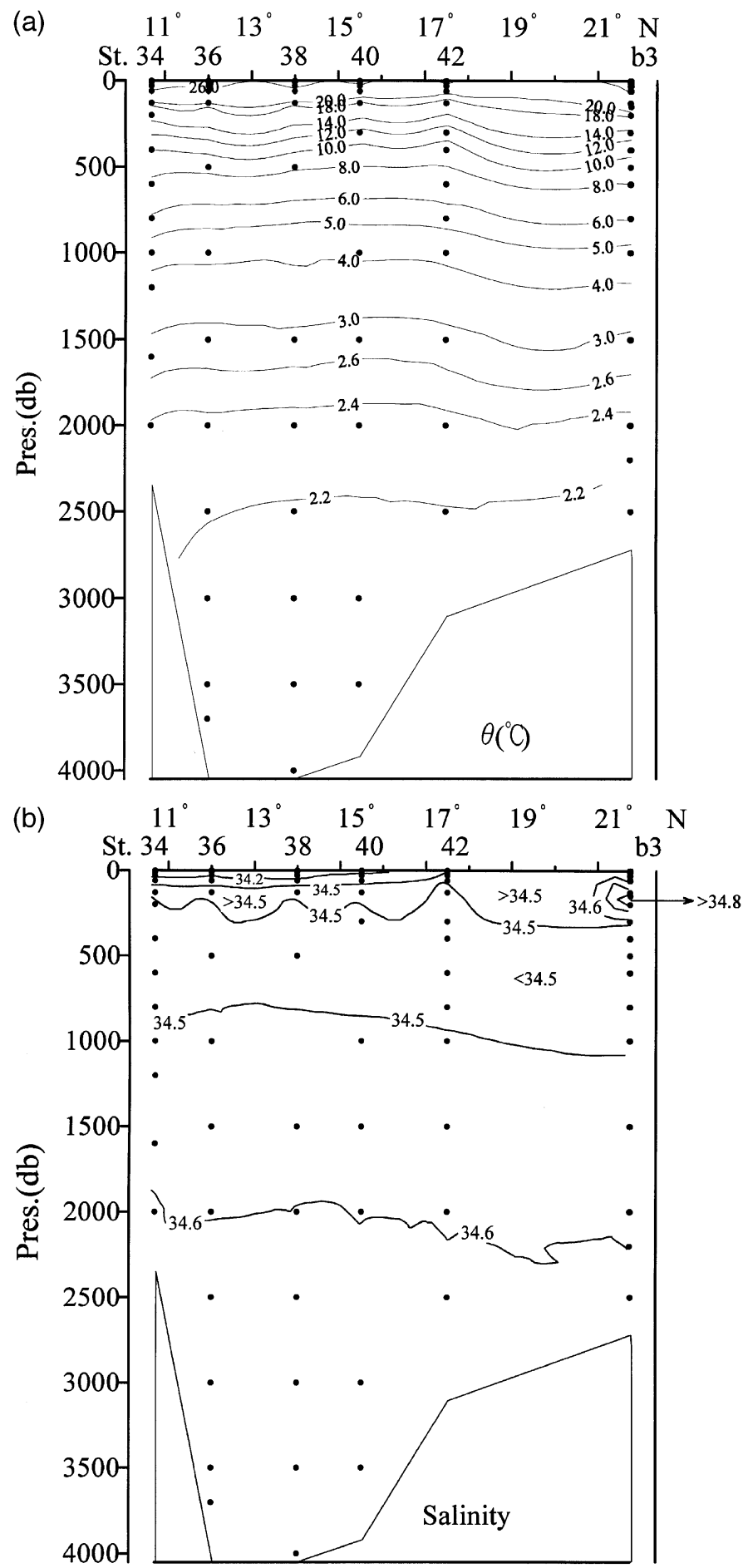

Fig. 3. North-south cross-sections of (a) $\theta$, (b) $S$, (c) $\mathrm{AOU}$, (d) $\mathrm{PO}_{4}^{3-}$, (e) $\mathrm{NO}_{3}^{-}$and (f) $\mathrm{SiO}_{2}$ for OR 508 in the eastern part of the $\mathrm{South}$ China Sea. 
(c)

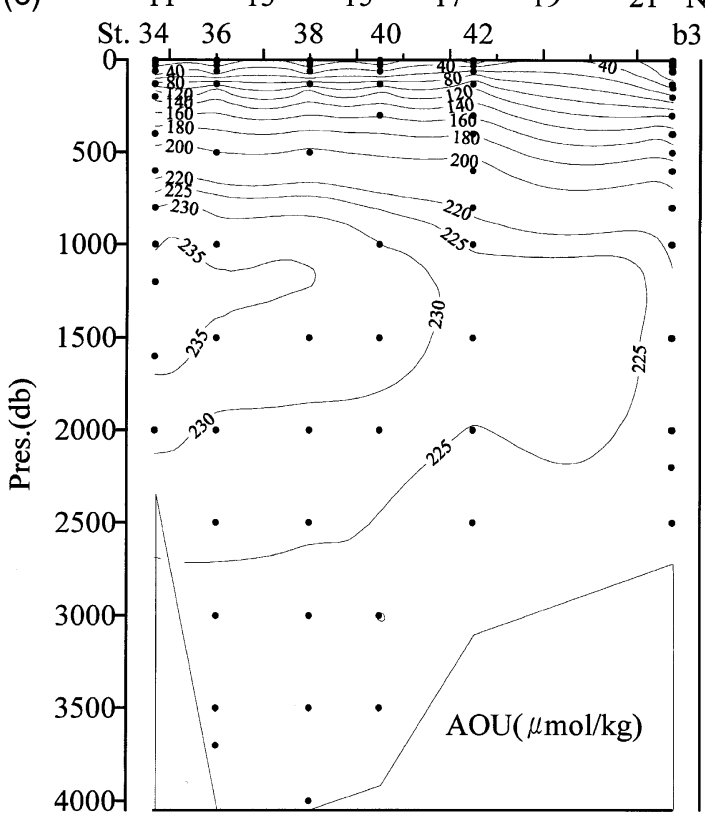

(e)

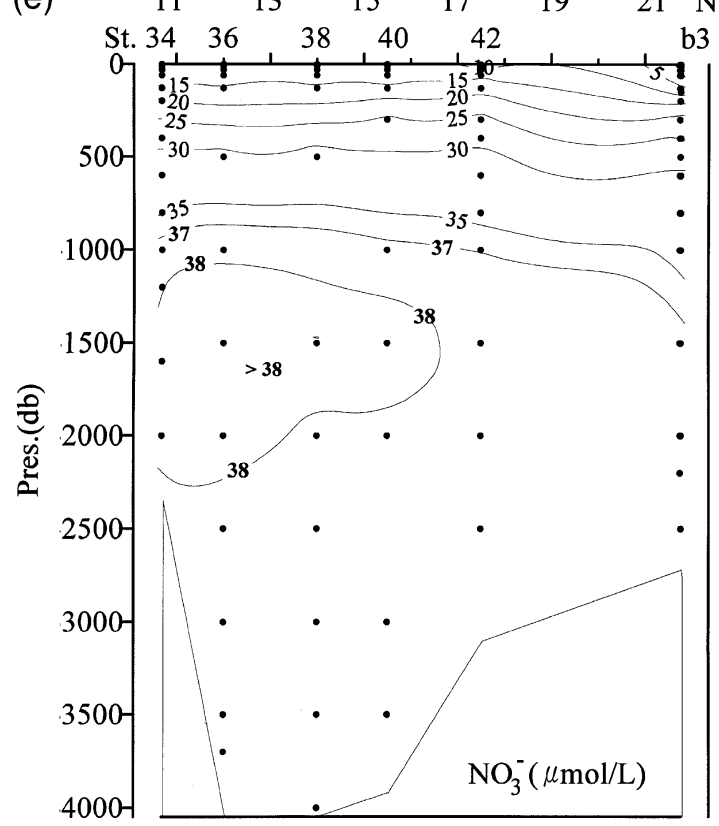

(d) $\quad \begin{array}{llllll}11^{\circ} & 13^{\circ} & 15^{\circ} & 17^{\circ} & 19^{\circ} & 21^{\circ} \mathrm{N}\end{array}$

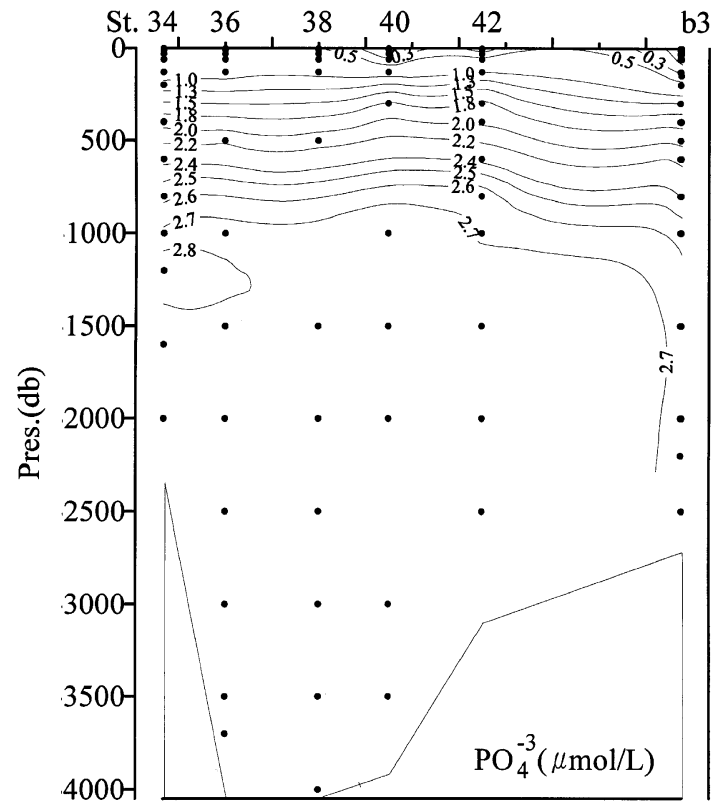

(f)

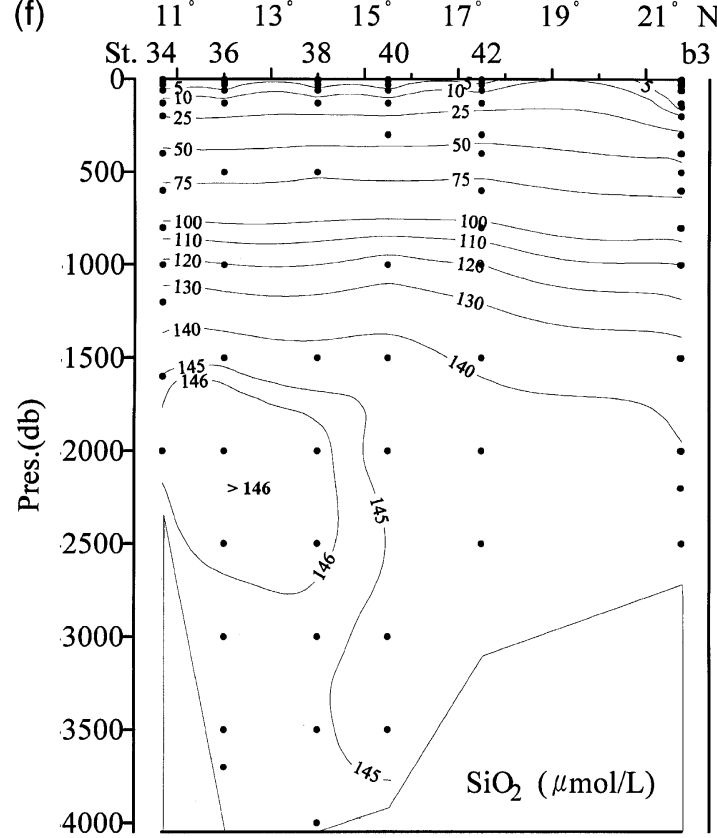

Fig. 3 (continued).

through the channel. The AOU data below $800 \mathrm{~m}$ are consistent with the flow pattern: younger waters with AOU below $225 \mu \mathrm{mol} \mathrm{kg} \mathrm{kg}^{-1}$ exist throughout the water column at the northernmost station, but exist only in the bottom water at the more southern stations. An AOU maximum, signifying older water, 
exists at about $1500 \mathrm{~m}$, and the signal seems to be clearer in the more southern stations. Nitrate (Fig. 3d) and phosphate (Fig. 3e) also have a maximum at

(a)

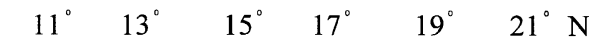

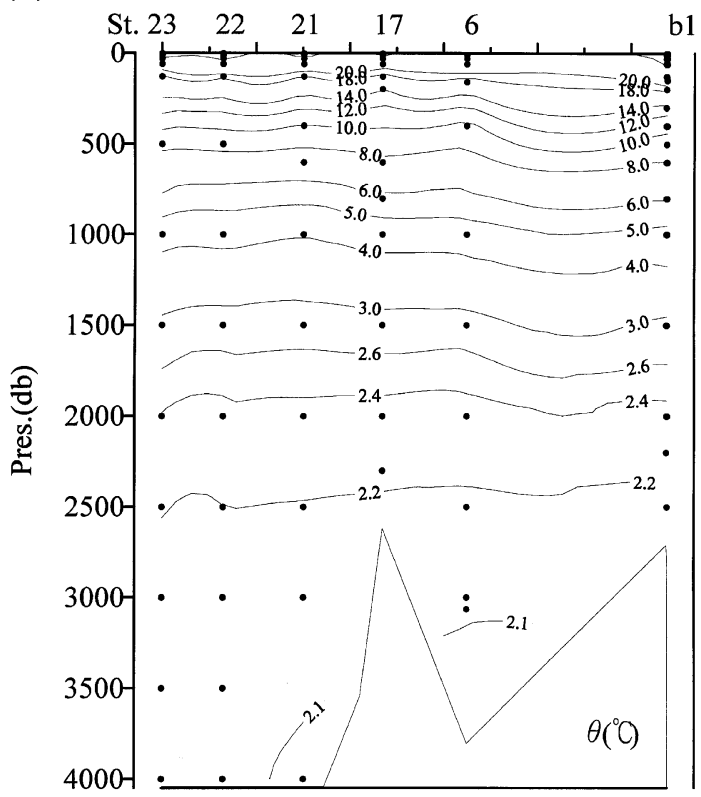

(c)

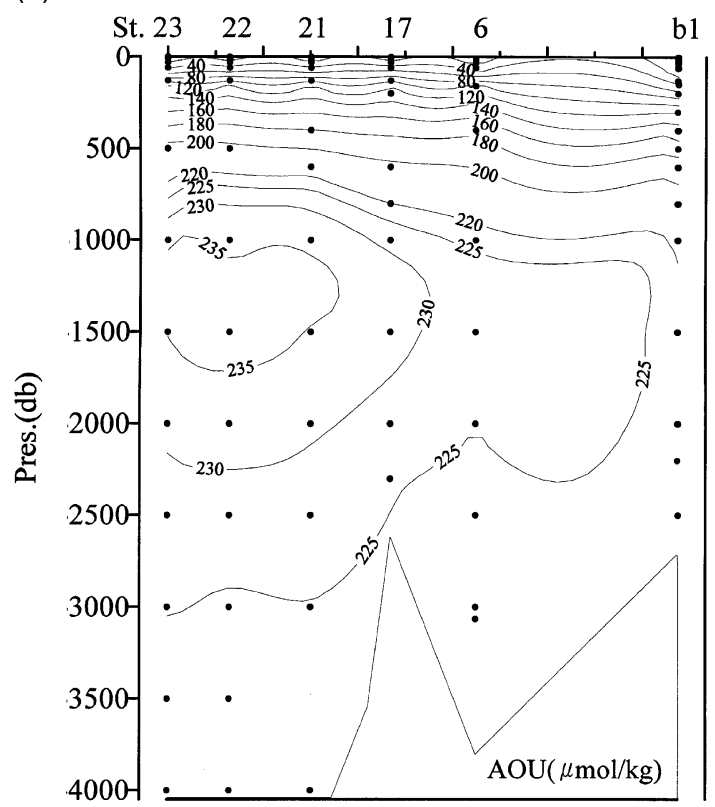

about $1500 \mathrm{~m}$ or slightly shallower. Silicate (Fig. 3f), however, has a deeper maximum at about $2200 \mathrm{~m}$ because the dissolution rate of siliceous shells is (b) $\quad \begin{array}{lllllll} & 11^{\circ} & 13^{\circ} & 15^{\circ} & 17^{\circ} & 19^{\circ} & 21^{\circ} \quad \mathrm{N}\end{array}$

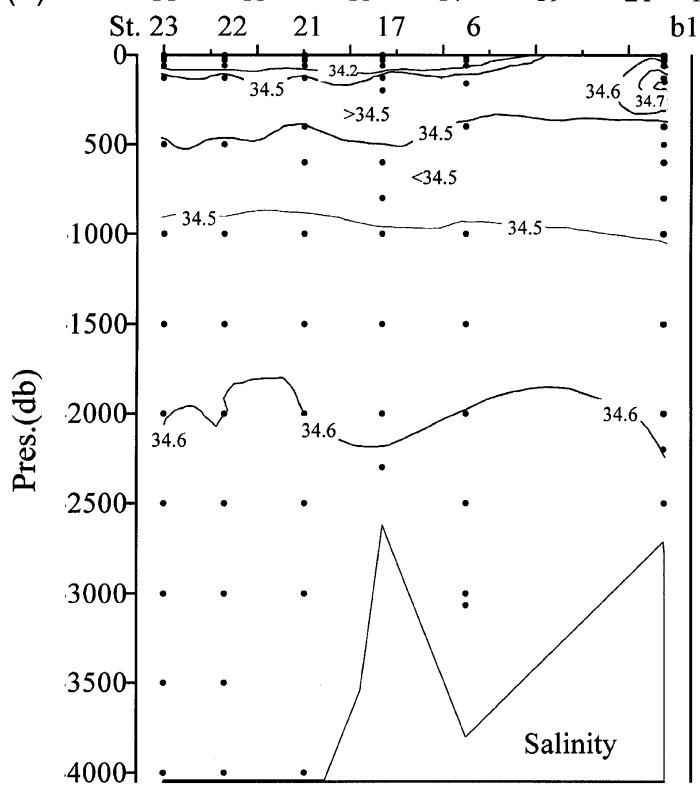

(d)

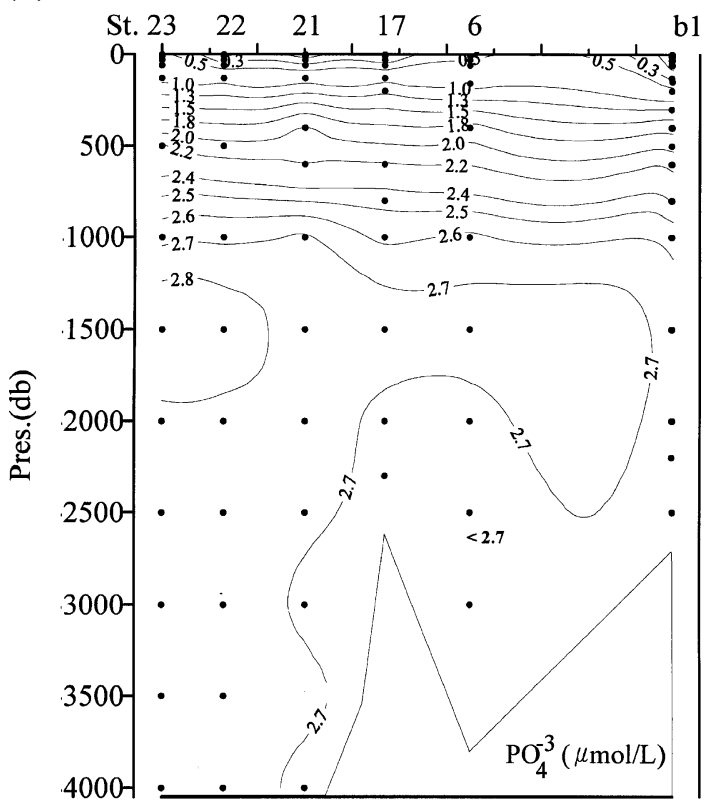

Fig. 4. North-south cross-sections of (a) $\theta$, (b) $S$, (c) $\mathrm{AOU}$, (d) $\mathrm{PO}_{4}^{3-}$, (e) $\mathrm{NO}_{3}^{-}$and (f) $\mathrm{SiO}_{2}$ for OR 508 in the western part of the South China Sea. 
(e)

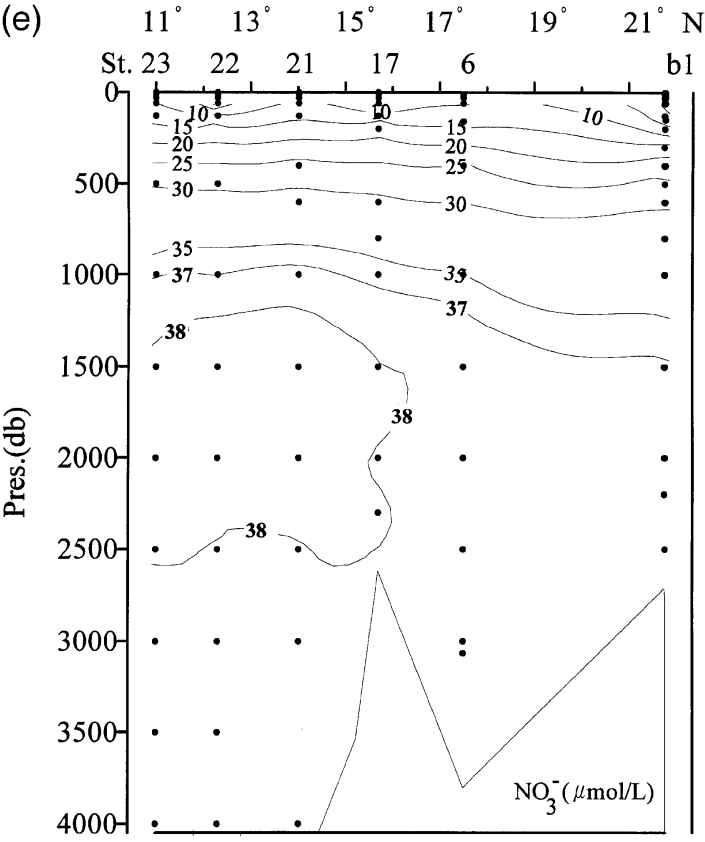

(f)

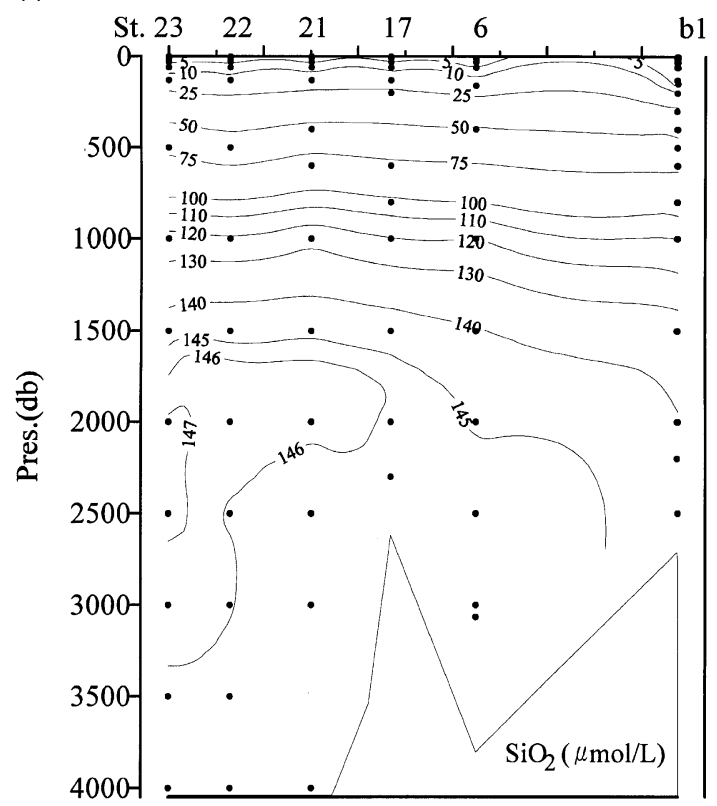

Fig. 4 (continued).

lower than the decomposition rate of organic particles. These nutrient data are also consistent with the flow pattern.
Fig. 4a-f shows the corresponding north-south cross-sections of $\theta, S, \mathrm{AOU}$, nitrate, phosphate and silicate in the western part of the SCS basin. The general features are similar to those found in the eastern basin, which is consistent with the notion that the SCS flushes rapidly. The bottom water is extremely homogeneous, with a salinity of $34.608 \pm$ 0.001 in both the eastern and western basins and a potential temperature of $2.11 \pm 0.02{ }^{\circ} \mathrm{C}$. Within the precision of our measurements, no systematic differences in physical or chemical parameters could be distinguished for the bottom waters in the cross-sections.

\section{Water and salt budgets}

The principle of conservation of water mass and salt is applied to estimate water fluxes that have not been measured directly. Since there is a large seasonal contrast in the SCS, budgets are calculated for both wet and dry seasons. The principle of conservation of water mass dictates that the water flowing into the SCS must be balanced by the water flowing out plus the water piled up within the SCS. Over the years, there can be no accumulation, but there is indeed a sea-level change between wet and dry seasons. Given that the sea level varies $10 \mathrm{~cm}$ between the wet and dry seasons, the water balance for the SCS is:

$$
\begin{gathered}
Q_{\mathrm{Ri}}+Q_{\mathrm{P}}+Q_{\mathrm{SSW}}+Q_{\mathrm{MSW}}+Q_{\mathrm{KSW}}+Q_{\mathrm{DW}} \\
=Q_{\mathrm{E}}+Q_{\mathrm{TSW}}+Q_{\mathrm{SCSW}}+Q_{\mathrm{IW}}+\Delta Q,
\end{gathered}
$$

where $Q$ is the water flux in weight unit, and the subscripts Ri, P, SSW, MSW, KSW, DW, E, TSW, SCSW and IW denote river input, precipitation, Sunda Shelf water, Mindoro Strait water, Kuroshio surface water, deep water, evaporation, Taiwan Strait water, SCS surface water and intermediate water, respectively. $\Delta Q$ denotes the accumulation or release of water due to sea-level changes. All fluxes are average values for the wet and the dry seasons, each 6 months long. 

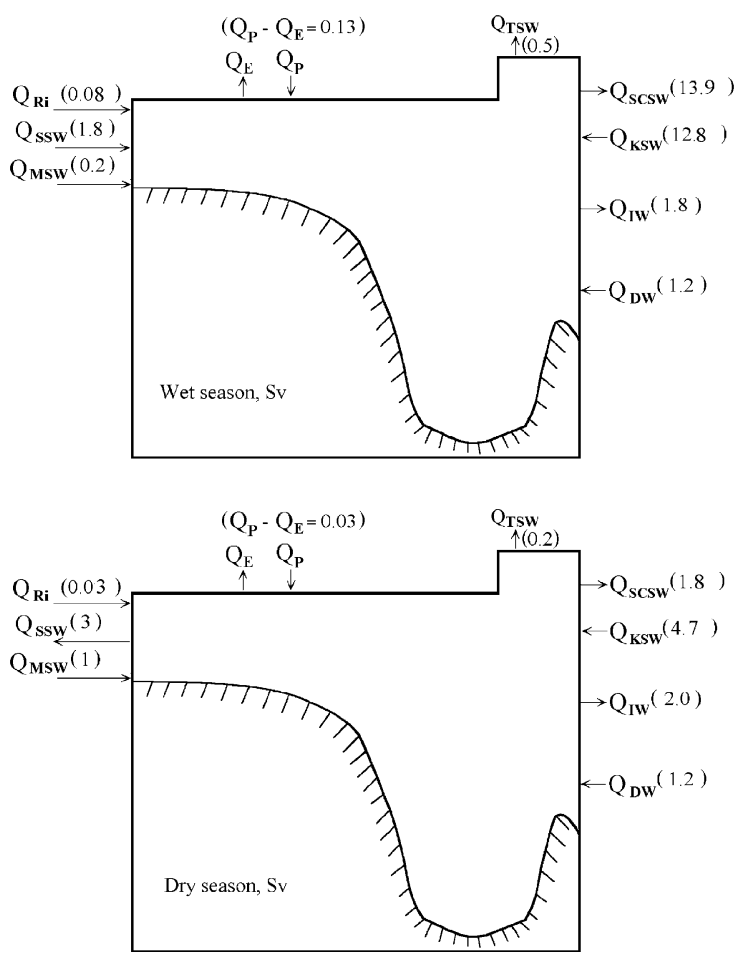

Fig. 5. Water budgets in the wet and dry seasons.

Because of large differences between the wet (May-October) and dry seasons (November-April), the box model (Fig. 5) was applied for each season.
In the wet season, the volume of precipitation $\left(Q_{\mathrm{P}}\right)$ exceeds evaporation $\left(Q_{\mathrm{E}}\right)$ by $0.13 \times 10^{6} \mathrm{t} \mathrm{s}^{-1}$. The volumes of groundwater and sewage inflows are not known, but are assumed to be $10 \%$ of the river runoff. The $Q_{\mathrm{Ri}}\left(0.08 \times 10^{6} \mathrm{t} \mathrm{s}^{-1}\right)$ therefore represents the sum of all three (Wyrtki, 1961; Han, 1995; Milliman et al., 1995).

The salt balance is:

$$
\begin{aligned}
Q_{\mathrm{Ri}} & S_{\mathrm{Ri}}+Q_{\mathrm{SSW}} S_{\mathrm{SSW}}+Q_{\mathrm{MSW}} S_{\mathrm{MSW}} \\
& +Q_{\mathrm{KSW}} S_{\mathrm{KSW}}+Q_{\mathrm{DW}} S_{\mathrm{DW}} \\
= & Q_{\mathrm{TSW}} S_{\mathrm{TSW}}+Q_{\mathrm{SCSW}} S_{\mathrm{SCSW}}+Q_{\mathrm{IW}} S_{\mathrm{IW}}+\Delta Q_{\mathrm{S}},
\end{aligned}
$$

where $S$ is the salinity and $\Delta Q_{\mathrm{S}}$ is the accumulation or release of salt mainly due to the difference in salinity between the wet and dry seasons.

The salinity of various water masses is listed in Table 1. The flow through the Strait of Malacca is taken as zero. For the wet season, the Java and Sulu Seas export $2 \times 10^{6} \mathrm{t} \mathrm{s}^{-1}$ seawater $\left(Q_{\mathrm{SSw}}\right.$; Table 1$)$ into the SCS. The outflow through the Taiwan Strait is $0.5 \times 10^{6} \mathrm{t} \mathrm{s}^{-1}\left(Q_{\mathrm{TSW}}\right)$. The intermediate water between 350 and $1350 \mathrm{~m}$ is a mixture of the upwelled deep water and surface water. The deep water

\begin{tabular}{|c|c|c|c|c|c|}
\hline & \multicolumn{2}{|c|}{ Wet season } & \multicolumn{2}{|c|}{ Dry season } & \multirow[t]{2}{*}{ References } \\
\hline & $S$ & Flux & $S$ & Flux & \\
\hline $\mathrm{Ri}$ & 0 & $0.08( \pm 0.02)$ & 0 & $0.03( \pm 0.01)$ & Milliman et al. (1995), this work \\
\hline$Q_{\mathrm{P}}-Q_{\mathrm{E}}$ & 0 & 0.13 & 0 & 0.03 & Wyrtki (1961) \\
\hline SSW & 32.2 & 1.8 & 32.4 & -3 & $\begin{array}{l}\text { Wyrtki (1961), Chu (1972), NOAA (1994a), } \\
\text { Frische and Quadfasel (1990) }\end{array}$ \\
\hline MSW & 33.4 & 0.2 & 33.4 & 1 & $\begin{array}{l}\text { Wyrtki (1961), INDOPAC (1978), } \\
\text { Frische and Quadfasel (1990), NOAA (1994a) }\end{array}$ \\
\hline TSW & 33.8 & -0.5 & 34 & -0.2 & $\begin{array}{l}\text { Fujien Oceanological Institute (1988), Zhang et al. (1991), } \\
\text { Wang and Chen (1992), Wang and Yuan (1997), } \\
\text { Chen and Wang (1999) }\end{array}$ \\
\hline SCSW & 34.33 & $-13.9( \pm 1.8)$ & 34.4 & $-1.8( \pm 0.2)$ & Chen et al. (1996a, 1997, 1998), this work \\
\hline KSW & 34.75 & $12.8( \pm 1.1)$ & 34.85 & $4.7( \pm 0.4)$ & Chen et al. (1996a, 1997, 1998), this work \\
\hline IW & 34.51 & $-1.8( \pm 0.4)$ & 34.52 & $-2.0( \pm 0.4)$ & Han (1995), Chen et al. (1996a, 1997, 1998), this work \\
\hline DW & 34.6 & $1.2( \pm 0.2)$ & 34.6 & $1.2( \pm 0.2)$ & Liu and Liu (1988), Chen et al. (1996a, 1997, 1998) \\
\hline
\end{tabular}

Table 1

Salinity and water fluxes $\left(\times 10^{6} \mathrm{t} \mathrm{s}^{-1}\right)$ of various water masses for the South China Sea

Positive and negative numbers represent inflow and outflow, respectively. 
below $1350 \mathrm{~m}$ flows into the SCS year-round at the rate of $1.2 \times 10^{6} \mathrm{t} \mathrm{s}^{-1}\left(Q_{\mathrm{DW}}\right)$ :

$Q_{\mathrm{IW}}=Q_{\mathrm{DW}}+Q_{\mathrm{Smix}}$,

and

$Q_{\mathrm{IW}} S_{\mathrm{IW}}=Q_{\mathrm{DW}} S_{\mathrm{DW}}+Q_{\mathrm{Smix}} S_{\mathrm{SCSW}}$,

where $Q_{\mathrm{Smix}}$ is the amount of surface water mixed in. The $Q_{\text {IW }}$ calculated from these two equations for the wet season is $1.5 Q_{\mathrm{DW}}$ or $1.8 \times 10^{6} \mathrm{t} \mathrm{s}^{-1}$, which flows out of the SCS (Chao et al., 1996; Chen and Huang, 1996; Chen et al., 1996a, 1997).

As for salt balance, it is assumed that the annual average conditions remain steady over a long time period in the SCS, but that in the wet season, the surface water above $350 \mathrm{~m}$ becomes fresher with exports of $8.8 \times 10^{19} \mathrm{~g}$ of salt. In the dry season, the SCS accumulates the same amount of salt. Given the above, the amount of surface water flowing out of the SCS through the Bashi Channel $\left(Q_{\mathrm{SCSW}}\right)$ in the wet season is calculated at $13.9 \times 10^{6} \mathrm{t} \mathrm{s}^{-1}$ and the Kuroshio water flowing into the $\operatorname{SCS}\left(Q_{\mathrm{KSW}}\right)$ is $12.8 \times 10^{6} \mathrm{t} \mathrm{s}^{-1}$ (Fig. 2).

For the dry season, $Q_{\mathrm{P}}-Q_{\mathrm{E}}=0.03 \times 10^{6} \mathrm{t} \mathrm{s}^{-1}$ and $Q_{\mathrm{Ri}}=0.03 \times 10^{6} \mathrm{t} \mathrm{s}^{-1}$. The SCS exports $3 \times$ $10^{6} \mathrm{t} \mathrm{s}^{-1}$ seawater into the Java Sea but imports $1 \times 10^{6} \mathrm{t} \mathrm{s}^{-1}$ from the Sulu Sea. The outflow through the Taiwan Strait is $0.2 \times 10^{6} \mathrm{t} \mathrm{s}^{-1}$. The deep inflow is taken as $1.2 \times 10^{6} \mathrm{t} \mathrm{s}^{-1}$ and the intermediate water outflow is $1.67 Q_{\mathrm{DW}}$ or $2.0 \times 10^{6}$ $\mathrm{t} \mathrm{s}^{-1}$ based on Eqs. (3) and (4). From the box model, the $Q_{\mathrm{SCSW}}$ is calculated at $1.8 \times 10^{6} \mathrm{t} \mathrm{s}^{-1}$, and the $Q_{\mathrm{Ksw}}$ at $4.7 \times 10^{6} \mathrm{t} \mathrm{s}^{-1}$. Indeed, higher fluxes have been observed in the Bashi Channel, but a large portion of the exchange is at or near the channel and does not really enter the SCS (Wyrtki, 1961; Chao et al., 1996; Chen and Huang, 1996).

The exchange time of deep water in the system can be calculated simply as $\tau=$ (the mass in the SCS below $1350 \mathrm{~m}) / Q_{\mathrm{DW}}=1.5 \times 10^{15} \mathrm{t} / 1.2 \times 10^{6} \mathrm{t} \mathrm{s}^{-1}$; thus $\tau=40$ years. For the intermediate water, $\tau=$ (the mass in the SCS between 350 and $1350 \mathrm{~m}$ ) $/ Q_{\mathrm{IW}}$. The relevant mass is $0.7 \times 10^{15} \mathrm{t}$, and the average $Q_{\text {IW }}$ is $1.9 \times 10^{6} \mathrm{t} \mathrm{s}^{-1}$, so $\tau=12$ years relative to its source deep water, making the residence time of the intermediate water in the SCS 52 years. For the surface layer in the wet season, $\tau=$ (the mass in the
SCS above $350 \mathrm{~m}) /\left(Q_{\mathrm{Ri}}+Q_{\mathrm{P}}-Q_{\mathrm{E}}+Q_{\mathrm{SSW}}+\right.$ $\left.Q_{\mathrm{MSW}}+Q_{\mathrm{KSW}}\right)=1.23 \times 10^{15} \mathrm{t} /(0.08+0.13+1.8$ $+0.2+12.8) \times 10^{6} \mathrm{t} \mathrm{s}^{-1}$, hence $\tau=2.6$ years. In the dry season, the surface exchange time is $\tau=$ (the mass of the SCS above $350 \mathrm{~m}) /\left(Q_{\mathrm{Ri}}+Q_{\mathrm{P}}-Q_{\mathrm{E}}+\right.$ $\left.Q_{\mathrm{MSW}}+Q_{\mathrm{KSW}}\right)=1.23 \times 10^{15} \mathrm{t} /(0.03+0.03+1+$ 4.7) $\times 10^{6} \mathrm{t} \mathrm{s}^{-1}$; so $\tau=6.8$ years.

These exchange rates for the surface water are all longer than 6 months mainly because a rather thick surface layer $(350 \mathrm{~m})$ was selected in this study. The exchange rate for the top layer must be much higher than the layer below, say at $100 \mathrm{~m}$. On average, the 350-m-thick surface layer has a residence time of about 4.7 years.

\section{Phosphorus budgets}

The $\mathrm{P}$ balance is represented as:

$$
\begin{aligned}
Q_{\mathrm{Ri}} & Y_{\mathrm{Ri}}+Q_{\mathrm{SSW}} Y_{\mathrm{SSW}}+Q_{\mathrm{KSW}} Y_{\mathrm{KSW}} \\
& +Q_{\mathrm{DW}} Y_{\mathrm{DW}}+Q_{\mathrm{P}}+Q_{\mathrm{Re}} \\
= & Q_{\mathrm{TSW}} Y_{\mathrm{TSW}}+Q_{\mathrm{SCSW}} Y_{\mathrm{SCSW}}+Q_{\mathrm{IW}} Y_{\mathrm{IW}}+Q_{\mathrm{B}},
\end{aligned}
$$

where $Y$ denotes the concentration of $\mathrm{P}$ in each medium, $Q_{\mathrm{P}}$ is the aerosol input, and $Q_{\mathrm{Re}}$ and $Q_{\mathrm{B}}$ are the amounts of $\mathrm{P}$ released from or deposited to the sediments. The relevant fluxes are given in Table 2 and in Fig. 6. There is an imbalance of $1.1 \times 10^{9}$ $\mathrm{mol}$ in the wet season, i.e. an accumulation of $\mathrm{P}$. The imbalance of $\mathrm{P}$ in the dry season is $-1.1 \times 10^{9} \mathrm{~mol}$, i.e. export of $P$. These figures and the zero annual imbalance all fall within the uncertainties of the calculation, lending support to the internal consistency of the water fluxes. It is noteworthy that the SCS exports $\mathrm{P}$ through the Bashi Channel because the import of $\mathrm{P}$ by the relatively $\mathrm{P}$-poor $\mathrm{KSW}$ is not sufficient to compensate for the export by the relatively P-rich SCSW. In addition, the outflowing intermediate water, with essentially all of its $\mathrm{P}$ supplied by the deep water, turns northward after leaving the Bashi Channel. Subsequently, this water upwells onto the ECS shelf, providing $\mathrm{P}$ to the shelf water which is short of $\mathrm{P}$ relative to $\mathrm{N}$ (Chen et al. 1995; Chen, 1996). Rivers play a relatively insignifi- 
Table 2

Concentrations $\left(\mu \mathrm{mol} \mathrm{kg}{ }^{-1}\right)$ and fluxes $\left(\times 10^{9}\right.$ mol for 6 months $)$ of $\mathrm{P}$ for the South China Sea

\begin{tabular}{|c|c|c|c|c|c|}
\hline & \multicolumn{2}{|l|}{ Wet season } & \multicolumn{2}{|l|}{ Dry season } & \multirow[t]{2}{*}{ References } \\
\hline & Concentration & Flux & Concentration & Flux & \\
\hline $\mathrm{Ri}$ & 0.7 & $0.9( \pm 0.2)$ & 0.7 & $0.3( \pm 0.06)$ & Meybeck (1993), Han (1995), Zhang (1996) \\
\hline SSW & 0.2 & 5.8 & 0.12 & -5.8 & Wyrtki (1961), Chu (1972), NOAA (1994b) \\
\hline MSW & 0.2 & 0.7 & 0.2 & 3.2 & $\begin{array}{l}\text { INDOPAC (1978), NOAA (1994b), } \\
\text { San Diego-McGlone et al. (1999) }\end{array}$ \\
\hline TSW & 0.2 & -1.6 & 0.2 & -0.6 & $\begin{array}{l}\text { Fujien Oceanological Institute (1988), } \\
\text { Wang (1991), Hong (1994), Hong and Dai (1994), } \\
\text { Chen and Wang }(1998,1999)\end{array}$ \\
\hline SCSW & 0.12 & $-26.8( \pm 3.5)$ & 0.12 & $-3.4( \pm 0.3)$ & Han (1995), Chen et al. (1996a, 1997, 1998), this work \\
\hline KSW & 0.1 & $20.6( \pm 1.9)$ & 0.1 & $7.6( \pm 0.7)$ & Chen et al. (1996a, 1997, 1998), this work \\
\hline IW & 1.67 & $-48.5( \pm 9.6)$ & 1.67 & $-54.0( \pm 10.8)$ & Han (1995), Chen et al. (1996a, 1997, 1998), this work \\
\hline $\begin{array}{l}\text { DW } \\
\text { B-Re }\end{array}$ & 2.71 & $\begin{array}{c}52.5( \pm 10.5) \\
-2.6( \pm 0.8)\end{array}$ & 2.71 & $\begin{array}{c}52.5( \pm 10.5) \\
-0.9( \pm 0.3)\end{array}$ & $\begin{array}{l}\text { Han (1995), Chen et al. (1996a, 1997, 1998), this work } \\
\text { Lai and Liu, 1994, } \\
\text { Su and Wang, 1994, Wang, 1999, this work }\end{array}$ \\
\hline
\end{tabular}

Positive and negative numbers represent inflow and outflow, respectively.

cant role in sustaining high productivity in either the ECS (Chen and Wang, 1999) or the SCS. The net P deposition in the sediment alone is greater than the

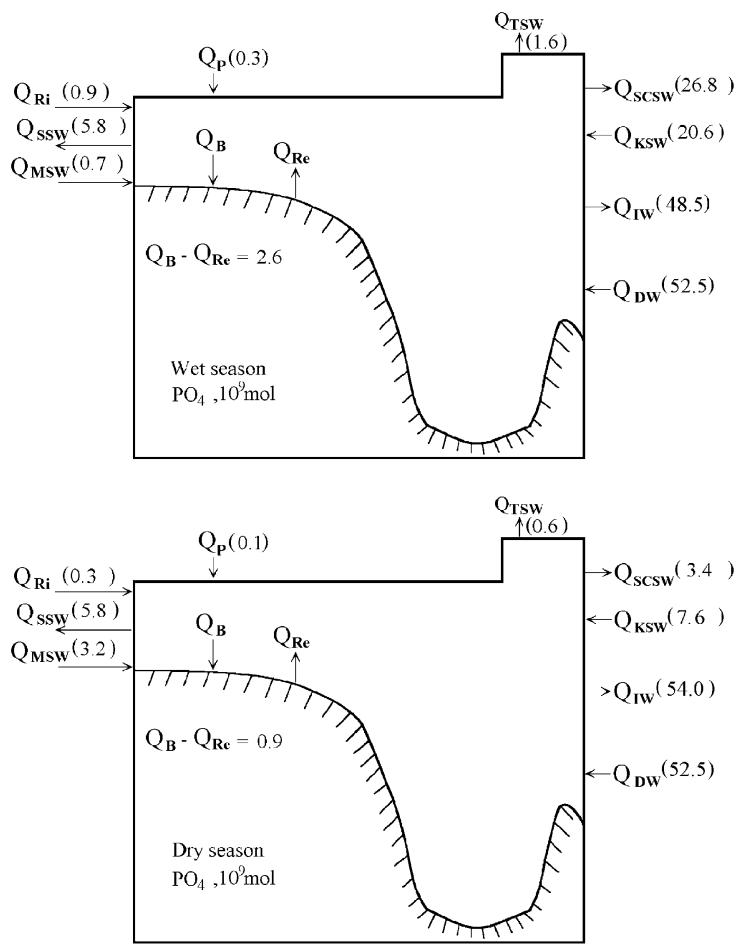

Fig. 6. P budgets in the wet and dry seasons. riverine input. Supplies from the Sulu Sea and from upwelling provide the $\mathrm{P}$ needed for new production.

\section{Nitrogen budgets}

Nitrogen fluxes are more complicated since acid deposition $\left(Q_{\mathrm{P}}\right)$ adds nitrogen to the SCS. Further, nitrogen fixation by cyanobacteria utilizes $\mathrm{N}_{2}$, thereby contributing additional nitrogen to the SCS. On the other hand, denitrification converts nitrate to $\mathrm{NH}_{3}, \mathrm{~N}_{2} \mathrm{O}$ and $\mathrm{N}_{2}$, which degas at the air-sea interface. No data regarding either nitrogen fixation or denitrification in the SCS is available. The unknown net air-sea exchange is taken to be $Q_{\mathrm{N}_{2}}$, which is calculated by balancing the nitrogen budget:

$$
\begin{aligned}
Q_{\mathrm{Ri}} & Y_{\mathrm{Ri}}+Q_{\mathrm{SSW}} Y_{\mathrm{SSW}}+Q_{\mathrm{KSW}} Y_{\mathrm{KSW}}+Q_{\mathrm{DW}} Y_{\mathrm{DW}} \\
& +Q_{\mathrm{P}}+Q_{\mathrm{Re}} \\
= & Q_{\mathrm{TSW}} Y_{\mathrm{TSW}}+Q_{\mathrm{SCSW}} Y_{\mathrm{SCSW}}+Q_{\mathrm{IW}} Y_{\mathrm{IW}} \\
& +Q_{\mathrm{B}}+Q_{\mathrm{N}_{2}} .
\end{aligned}
$$

The relevant fluxes are given in Table 3 and Fig. 7. Here, it was assumed that the imbalances are due to the differences in the rates of nitrogen fixation and denitrification. Accordingly, the $\mathrm{N}$ budget suggests net denitrification in both seasons, totaling 114 $( \pm 129) \times 10^{9} \mathrm{~mol} \mathrm{year}^{-1}$ or $0.03( \pm 0.04) \mathrm{mol} \mathrm{N}$ $\mathrm{m}^{-2}$ year $^{-1}$. This figure, although with a large 
Table 3

Concentrations $\left(\mu \mathrm{mol} \mathrm{kg}{ }^{-1}\right)$ and fluxes $\left(\times 10^{9}\right.$ mol for 6 months $)$ of $\mathrm{N}$ for the South China Sea

\begin{tabular}{|c|c|c|c|c|c|}
\hline & \multicolumn{2}{|l|}{ Wet season } & \multicolumn{2}{|l|}{ Dry season } & \multirow[t]{2}{*}{ References } \\
\hline & Concentration & Flux & Concentration & Flux & \\
\hline $\mathrm{Ri}$ & 60 & $73( \pm 15)$ & 60 & $24( \pm 5)$ & Meybeck (1993), Zhang (1996) \\
\hline SSW & 2 & 58 & 0.9 & -44 & Wyrtki (1961), Chu (1972), NOAA (1994b) \\
\hline MSW & 2 & 7 & 2 & 32 & $\begin{array}{l}\text { INDOPAC (1978), NOAA (1994b), } \\
\text { San Diego-McGlone et al. (1999) }\end{array}$ \\
\hline SCSW & 1.6 & $-358( \pm 47)$ & 1.6 & $-45( \pm 4)$ & Chen et al. (1996a, 1997, 1998), this work \\
\hline KSW & 1.4 & $288( \pm 26)$ & 1.4 & $106( \pm 10)$ & Chen et al. (1996a, 1997, 1998), this work \\
\hline IW & 23 & $-668( \pm 134)$ & 23 & $-743( \pm 148)$ & Chen et al. (1996a, 1997, 1998), this work \\
\hline
\end{tabular}

Positive and negative numbers represent inflow and outflow, respectively.

uncertainty, is smaller than that recorded in the ECS $\left(0.1 \mathrm{~mol} \mathrm{~N} \mathrm{~m}^{-2}\right.$ year $\left.^{-1}\right)$ or the North Sea (0.05-1.46 mol N m${ }^{-2}$ year $^{-1}$ ) (Chen and Wang, 1999). Codis-

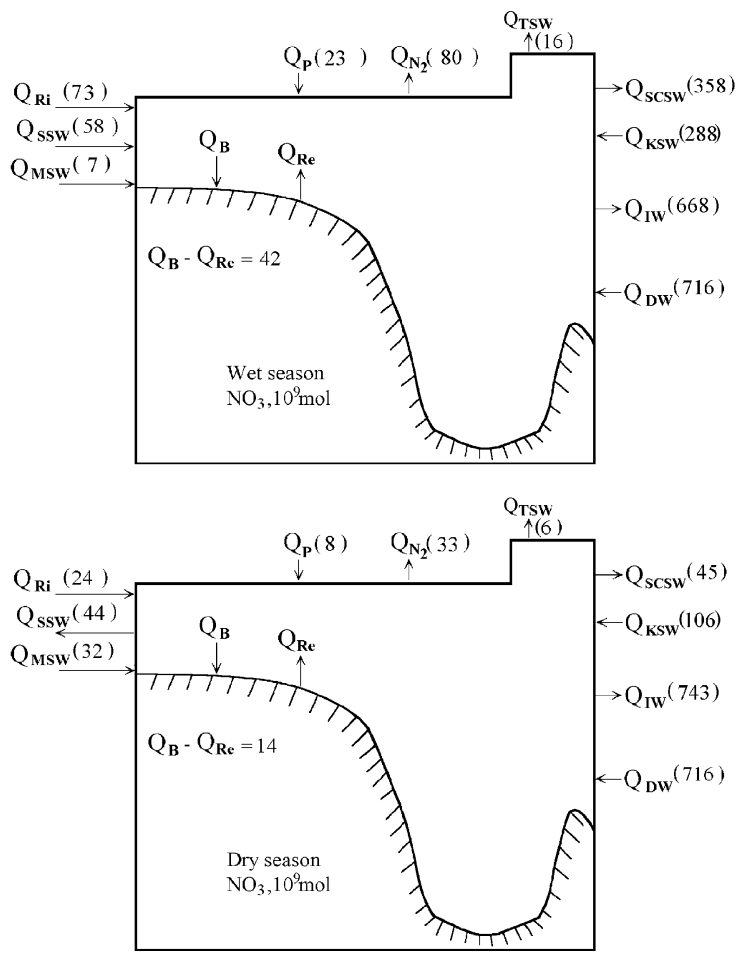

Fig. 7. $\mathrm{N}$ budgets in the wet and dry seasons. poti (1995) gave $0.06 \mathrm{~mol} \mathrm{~N} \mathrm{~m}^{-2}$ year $^{-1}$ as the gross denitrification rate for the global oceans. Middelburg et al. (1996) summarized the gross global denitrification rates in shelf sediments as between 0.32 and $0.37 \mathrm{~mol} \mathrm{~N} \mathrm{~m}^{-2}$ year $^{-1}$. Seitzinger and Giblin (1996) gave $0.25 \mathrm{~mol} \mathrm{~N} \mathrm{~m}^{-2}$ year $^{-1}$ (gross) in the North Atlantic shelf sediments. More recently, Wollast (1998) obtained a gross global shelf average of $0.137 \mathrm{~mol} \mathrm{~N} \mathrm{~m}^{-2}$ year $^{-1}$. If it is assumed that denitrification in the SCS occurs only on the shelf, then the net rate is $0.11 \pm 0.12 \mathrm{~mol} \mathrm{~N} \mathrm{~m}^{-2}$ year $^{-1}$, which is lower than the gross rates reported above. Since the nitrification rate in the SCS is not known, it is as yet not possible to estimate the gross rate. As with phosphate, a large amount of nitrate both in the SCSW and in the intermediate water is exported through the Bashi Channel.

Rivers flowing into the SCS, like the ECS, have very low phosphorus contents. The $\mathrm{N} / \mathrm{P}$ ratio is 86 , which is far greater than the Redfield ratio of 16 . If the phytoplankton depended solely on the riverine input of nutrients for their growth, the phosphorus would be depleted quickly although there would still be an excess of nitrate. On the other hand, the influx of seawater through the Sunda Shelf (only in the wet season), and the year-round upwelling and inflow through the Bashi Channel and the Mindoro Strait bring in seawater with an $\mathrm{N} / \mathrm{P}$ slightly lower than 
the Redfield ratio. These incoming seawater masses contribute to productivity in the SCS the most. Along with upwelling which occurs in the SCS (Shaw et al., 1996; Chao et al., 1996), the intermediate water transports more nitrate and phosphate out of the SCS than the deep water brings in. The excess can only come from the decomposition of sinking organic particles, which is discussed later.

\section{Silicate budgets}

The Si balance can also be represented by Eq. (5). The relevant fluxes are given in Table 4 and Fig. 8. Unlike $\mathrm{P}$ and $\mathrm{N}$, far less $\mathrm{Si}$ is transported out of the SCS by the intermediate water than is brought in through deep-water influx. This is because siliceous particles do not dissolve as readily as organic particles decompose. This means a larger portion of $\mathrm{Si}$ reaches the sediment. The net burial of biogenic silica is taken as the residual in the box model and is 155 and $132 \times 10^{9}$ mol for 6 months for the wet and dry seasons, respectively. These fluxes are large compared with $\mathrm{P}$ and $\mathrm{N}$, but is small compared with the total sediment deposit. This is because only the biogenic siliceous particles produced from dissolved $\mathrm{Si}$ in the SCS was taken into account. Aeolian dust particles and suspended particles, such as sand, transported by rivers, were not included. Note the SCSW transports about $2 \times 10^{12} \mathrm{~mol}$ of $\mathrm{Si}$ a year

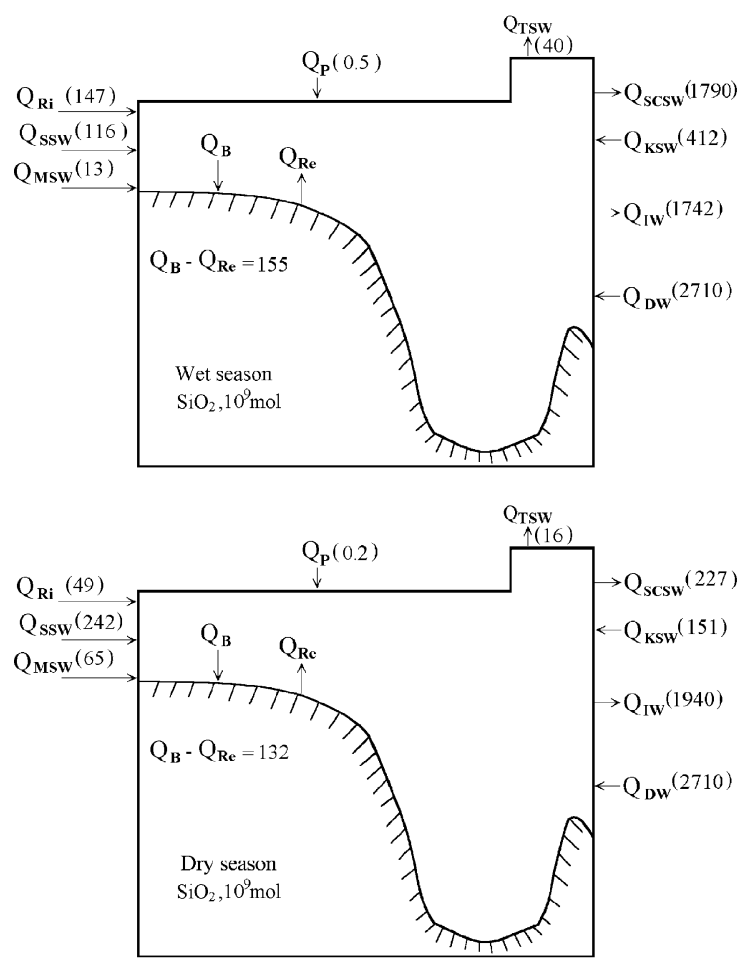

Fig. 8. Si budgets in the wet and dry seasons.

out of the SCS vs. $0.56 \times 10^{12}$ mol input from $\mathrm{KSW}$. The net export is an order of magnitude more than the riverine input. Much of this excess comes from the upwelling of deep waters.

Table 4

Concentrations $\left(\mu \mathrm{mol} \mathrm{kg}{ }^{-1}\right)$ and fluxes $\left(\times 10^{9}\right.$ mol for 6 month) of Si for the South China Sea

\begin{tabular}{|c|c|c|c|c|c|}
\hline & \multicolumn{2}{|l|}{ Wet season } & \multicolumn{2}{|l|}{ Dry season } & \multirow[t]{2}{*}{ References } \\
\hline & Concentration & Flux & Concentration & Flux & \\
\hline $\mathrm{Ri}$ & 121 & $147( \pm 29)$ & 121 & $49( \pm 10)$ & Meybeck (1993), Han (1995), Zhang (1996) \\
\hline$Q_{\mathrm{P}}$ & - & 0.5 & - & 0.2 & Wyrtki (1961), Chu (1972) \\
\hline SSW & 4 & 116 & 5 & -242 & Wyrtki (1961), Chu (1972), NOAA (1994b) \\
\hline MSW & 4 & 13 & 4 & 65 & $\begin{array}{l}\text { INDOPAC (1978), Frische and Quadfasel (1990), } \\
\text { NOAA (1994b), San Diego-McGlone et al. (1999) }\end{array}$ \\
\hline TSW & 5 & -40 & 5 & -16 & $\begin{array}{l}\text { Fujien Oceanological Institute (1988), Wang (1991), } \\
\text { Hong and Dai (1994), Chen and Wang (1998, 1999) }\end{array}$ \\
\hline SCSW & 8 & $-1790( \pm 232)$ & 8 & $-227( \pm 20)$ & Han (1995), Chen et al. (1996a, 1997, 1998), this work \\
\hline KSW & 2 & $412( \pm 37)$ & 2 & $151( \pm 14)$ & Chen et al. (1996a, 1997, 1998), this work \\
\hline IW & 60 & $-1742( \pm 157)$ & 60 & $-1940( \pm 175)$ & Han (1995), Chen et al. (1996a, 1997, 1998), this work \\
\hline DW & 140 & $2710( \pm 542)$ & 140 & $2710( \pm 542)$ & Han (1995), Chen et al. (1996a, 1997, 1998), this work \\
\hline $\mathrm{B}-\mathrm{Re}$ & - & $-155( \pm 47)$ & - & $-132( \pm 40)$ & This work \\
\hline
\end{tabular}

Positive and negative numbers represent inflow and outflow, respectively. 


\section{Error analysis}

The above results must be interpreted with a certain degree of caution since they are of a preliminary nature. Insufficient data are available for seawater fluxes and nutrient concentrations across the Sunda Shelf and the Mindoro Strait. These fluxes are large (Wyrtki, 1961) and may even significantly contribute to the Pacific Indian Ocean throughflow (Metzger and Hurlburt, 1995). Another great uncertainty concerns the amount of deep water inflow through the Bashi Channel. This value is the most sensitive term in Eqs. (1) and (2). Errors in $Q_{\mathrm{DW}}$, estimated at $\pm 20 \%$, result in $\pm 20 \%$ error in all fluxes related to IW. These errors propagate to $\pm 10 \%$ error in fluxes related to SCSW in the dry season and $\pm 1 \%$ error in the wet season. Another sensitive item is the riverine freshwater flux where fluctuations of $\pm 20 \%$ are not unusual. These would propagate to $\pm 9 \%$ errors in fluxes related to $\mathrm{KSW}$ and SCSW. Altogether, the errors in $Q_{\mathrm{DW}}$ and $Q_{\mathrm{Ri}}$ propagate to, respectively, $\pm 13 \%$ and $\pm 9 \%$ in $Q_{\mathrm{SCSW}}$ and $Q_{\mathrm{KSW}}$ in the wet season and $9 \%$ in both $Q_{\mathrm{SCSW}}$ and $Q_{\mathrm{KSW}}$ in the dry season. These uncertainties, in absolute terms, are given in Tables 1-4. The largest relative uncertainty is in the net denitrification rate. The Sunda Shelf fluxes are also critical, but there are no estimates other than those of Wyrtki(1961). Since nutrient concentrations are known to better than $\pm 1 \%$, errors in nutrient fluxes are mainly due to errors in the water fluxes mentioned above. Since there are no data, however, organic nutrients were not considered in the calculations here.

\section{Decomposition rates of particles}

Since the SCS is semi-enclosed, the calculation of the decomposition and dissolution rates of particles based on the mass-balance method is straightforward. The approach assumes that the source of the deep SCS water is at $2000 \mathrm{~m}$ immediately outside the Bashi Channel. The water in the SCS proper, say at $2000 \mathrm{~m}$, is between 40 and 52 years older than the source water, and the increase in AOU, nitrate, phosphate and silicate are $27 \pm 2,2.47 \pm 0.10,0.16$ \pm 0.02 and $8 \pm 2 \mu \mathrm{mol} \mathrm{kg}{ }^{-1}$, respectively. These increases have $\mathrm{O} / \mathrm{N}$ and $\mathrm{N} / \mathrm{P}$ ratios of $10.9 \pm 2.0$ and $15 \pm 2$, respectively, and are in good agreement with the Redfield ratios of 8.6 and 16 (Chen et al., 1996b). The rates of increase (in $\mu \mathrm{mol} \mathrm{kg}{ }^{-1}$ year $^{-1}$ ) are: $0.59 \pm 0.12$ (AOU), $0.054 \pm 0.016$ (nitrate), $0.0035 \pm 0.0010$ (phosphate) and $0.17 \pm 0.05$ (silicate).

For waters between about 800 and $3000 \mathrm{~m}$ where the $\theta / S$ plot is relatively linear, the one dimensional advection-diffusion model can be performed following the method of Craig and Weiss (1970). The resultant $J / W$ for oxygen, nitrate, phosphate and silicate are $-5.40 \pm 1.00,0.81 \pm 0.17,0.09 \pm 0.04$ and $4.70 \pm 0.11 \mu \mathrm{mol} \mathrm{kg} \mathrm{km}^{-1}$, respectively, where $J$ is the consumption or production rate, and $W$ is the upwelling rate. These rates represent $\mathrm{O} / \mathrm{N}$ and $\mathrm{N} / \mathrm{P}$ ratios of $6.7 \pm 2.0$ and $9 \pm 4$, respectively, both lower than the Redfield ratios.

The upwelling rate of $0.055 \mathrm{~km} \mathrm{year}^{-1}$ was obtained by dividing the distance (upwelling the 3000-m deep water to the 800-m intermediate depth) by the residence time of 40 years for deep water. The oxygen consumption rate from multiplying $J / W$ by the upwelling rate gives $0.30 \pm 0.06$ compared to $0.59 \pm 0.12 \mu \mathrm{mol} \mathrm{kg}^{-1}$ year $^{-1}$ from the mass-balance method above. The nitrate, phosphate and silicate production rates are $0.045 \pm 0.010,0.005 \pm$ 0.002 and $0.26 \pm 0.07 \mu \mathrm{mol} \mathrm{kg} \mathrm{km}^{-1}$, respectively. These are in fair agreement with the above estimations based on mass-balance.

These rates are compared with those for the Bering Sea and the Sea of Japan (Table 5). Clearly, the rates for the SCS sit in between, with the highest in the Sea of Japan and the lowest in the Bering Sea. It should be cautioned, however, that these rates have different reference states. The Bering Sea rates are relative to the source waters from the Weddell Sea, rendering the deep Bering Sea waters very old, to the order of 600 years (Chen et al., 1996c). For waters of the same local surface production and downward flux of sinking particles, older waters have fewer fine suspended particles left for decomposition or dissolution. Further, these particles are more refractory. In contrast, the Sea of Japan deep waters are very young, to the order of 120 years relative to the source within the Sea (Chen et al., 1996c). More particles remain for decomposition and the remaining particles are more labile, bringing about such high rates. The SCS deep water is only 40 years 
Table 5

Consumption or production rates of oxygen and nutrients in the deep South China Sea Basin $\left(\mu \mathrm{mol} \mathrm{kg} \mathrm{gear}^{-1}\right.$ )

\begin{tabular}{|c|c|c|c|c|}
\hline & \multicolumn{2}{|l|}{ SCS } & \multirow{2}{*}{$\frac{\text { Bering Sea }^{\mathrm{a}}}{\text { Mass balance }}$} & \multirow{2}{*}{$\frac{\text { Sea of Japan }^{\mathrm{a}}}{\text { Mass balance }}$} \\
\hline & Mass balance & 1-d model & & \\
\hline Oxygen consumption rate & $0.59 \pm 0.12$ & $0.30 \pm 0.06$ & 0.2 & $1.13 \pm 0.04$ \\
\hline $\mathrm{NO}_{3}$ production rate & $0.054 \pm 0.016$ & $0.045 \pm 0.010$ & 0.012 & $0.12 \pm 0.008$ \\
\hline $\mathrm{PO}_{4}$ production rate & $0.0035 \pm 0.0010$ & $0.005 \pm 0.002$ & 0.0011 & $0.0091 \pm 0.0004$ \\
\hline $\mathrm{SiO}_{2}$ production rate & $0.17 \pm 0.05$ & $0.26 \pm 0.07$ & 0.17 & $0.52 \pm 0.02$ \\
\hline
\end{tabular}

${ }^{\mathrm{a}}$ Taken from Chen et al. (1996c).

older than the source water, which is several hundred years old based on C-14 data (Broecker et al., 1986). As a result, the rates are much lower than those of the Sea of Japan.

\section{Conclusions}

Recent hydrographic and nutrient data collected in the SCS indicate that salinity, AOU and nutrient extremes are less pronounced than in the West Philippine Sea. This is because of the intensive upwelling and rapid flushing of the SCS. Box model results indicate that in the wet season, $13.9( \pm 1.8)$ Sv SCS surface water flows out of the Bashi Channel, while $12.8( \pm 1.1)$ Sv Kuroshio surface water enters it. The nutrient-rich SCSW exports 26.8 $( \pm 3.5) \times 10^{9} \mathrm{~mol} \mathrm{P}, 358( \pm 47) \times 10^{9} \mathrm{~mol} \mathrm{~N}$ and $1790( \pm 232) \times 10^{9} \mathrm{~mol} \mathrm{Si}$ out of the Bashi Channel, while the KSW imports $20.6( \pm 1.9) \times 10^{9} \mathrm{~mol}$ $\mathrm{P}, 288( \pm 26) \times 10^{9} \mathrm{~mol} \mathrm{~N}$ and $412( \pm 37) \times 10^{9}$ mol Si through the channel. The intermediate water flows out of the SCS at a rate of $1.8( \pm 0.36) \mathrm{Sv}$, carrying with it $48.5( \pm 9.6) \times 10^{9}$ mol $\mathrm{P}, 668$ $( \pm 134) \times 10^{9} \mathrm{~mol} \mathrm{~N}$ and $1742( \pm 157) \times 10^{9} \mathrm{~mol}$ Si. Balancing the $\mathrm{N}$ budgets gives a net denitrification rate of $80.4( \pm 91) \times 10^{9}$ mol over 6 months.

In the dry season, the fluxes are significantly reduced. The SCSW exports $1.8( \pm 0.2)$ Sv seawater, $3.4( \pm 0.3) \times 10^{9} \mathrm{~mol} \mathrm{P}, 45( \pm 4) \times 10^{9} \mathrm{~mol} \mathrm{~N}$ and $227( \pm 20) \times 10^{9} \mathrm{~mol} \mathrm{Si}$ out of the Bashi Channel, while the KSW imports $4.7( \pm 0.4)$ Sv seawater, 7.6 $( \pm 0.7) \times 10^{9} \mathrm{~mol} \mathrm{P}, 106( \pm 10) \times 10^{9} \mathrm{~mol} \mathrm{~N}$ and $151( \pm 14) \times 10^{9}$ mol Si through the channel. The SCS intermediate water exports $2.0( \pm 0.4) \mathrm{Sv}$ seawater, $54( \pm 11) \times 10^{9} \mathrm{~mol} \mathrm{P}, 743( \pm 148) \times 10^{9}$ mol $\mathrm{N}$ and $1940( \pm 175) \times 10^{9} \mathrm{~mol} \mathrm{Si}$ out of the
SCS through the Bashi Channel. The net denitrification rate is $33( \pm 92) \times 10^{9}$ mol over 6 months. The net export of nutrients in the SCSW is mainly supported by deep water inflow. The rate is $1.2( \pm 0.2)$ $\mathrm{Sv}$ seawater, $52.5( \pm 10.5) \times 10^{9} \mathrm{~mol} \mathrm{P}, 716$ $( \pm 143) \times 10^{9} \mathrm{~mol} \mathrm{~N}$ and $2710( \pm 542) \times 10^{9} \mathrm{~mol}$ $\mathrm{Si}$ in both the wet and dry seasons. The outflowing SCSW is relatively nutrient-rich compared with the $\mathrm{KSW}$, and plays an important role in the ECS. To a certain extent, the intermediate water also upwells onto the ECS shelf, thus providing nutrients to support its high productivity. As a result, the SCS acts as a pump which moves nutrients from the deep water and eventually to the euphotic zone.

\section{Acknowledgements}

The authors wish to thank the National Science Council for supporting this research (NSC89-2611M110-001). The assistance of C.T. Liu, M.H. Huang, $\mathrm{W}$. Lucas, and the captain and crew of the $\mathrm{R} / \mathrm{V}$ Ocean Researcher 1 is also greatly appreciated. Two anonymous reviewers and M. Altabet gave constructive criticisms, which strengthened the manuscript.

\section{References}

Ayers, G., Gillett, R., Hara, H., 1997. Acid deposition in East Asia and Oceanic. In: Whelpdale, D.M., Kaiser, M.S. (Eds.), Global Acid Deposition Assessment. World Meteorological Organization Global Atmosphere Watch No. 106, pp. 107-134.

Broecker, W.S., Patzert, W.C., Toggweilar, J.R., Stuiver, M., 1986. Hydrography, chemistry and radioisotopes in the Southeast Asian basins. J. Geophys. Res. 91, 14345-14354. 
Chao, S.Y., Shaw, P.T., Wu, S.Y., 1996. Deep water ventilation in the South China Sea. Deep-Sea Res. 43, 445-466.

Chen, C.T.A., 1981. Oxygen solubility in seawater. In: Battino, R. (Ed.), Solubility Data Series. Oxygen and Ozone, vol. 7, Pergamon, Oxford, pp. 41-55.

Chen, C.T.A., 1995. Fluxes of seawater and some dissolved chemicals in the Bashi Strait, Chin. J. Oceanol. Limnol. 13, 240-246.

Chen, C.T.A., 1996. The Kuroshio Intermediate Water is the major source of nutrients on the East China Sea continental shelf. Oceanol. Acta 19, 523-527.

Chen, C.T.A., Huang, M.H., 1995. Carbonate chemistry and the anthropogenic $\mathrm{CO}_{2}$ in the South China Sea. Acta Oceanol. Sin. 14, 47-57.

Chen, C.T.A., Huang, M.H., 1996. A mid-depth front separating the South China Sea water and the West Philippine Sea water. J. Oceanogr. 52, 17-25.

Chen, C.T.A., Wang, B.J., 1997. Acidification of lakes and reservoirs in Taiwan. Geochem. J. 31, 345-355.

Chen, C.T.A., Wang, S.L., 1998. Influence of intermediate water in the western Okinawa Trough by the outflow from the South China Sea. J. Geophys. Res. 103, 12683-12688.

Chen, C.T.A., Wang, S.L., 1999. Carbon, alkalinity and nutrient budgets on the East China Sea continental shelf. J. Geophys. Res. 104, 20675-20686.

Chen, C.T.A., Wang, B.J., Hsu, H.C., Hung, J.J., 1994. Rain and lake waters in Taiwan: composition and acidity. Terr. Atmos. Oceanic Sci. 5 (4), 573-584.

Chen, C.T.A., Ruo, R., Pai, S.C., Liu, C.T., Wong, G.T.F., 1995. Exchange of water masses between the East China Sea and the Kuroshio off northeastern Taiwan. Cont. Shelf Res. 15, 19-39.

Chen, C.T.A., Wang, S.L., Huang, M.H., 1996a. Preliminary data report of ocean researcher 1 cruises 403 and 418 B, Inst. Mar. Geol. Tech. Rep. No. 25, Nat. Sun Yat-sen Univ., 199 pp.

Chen, C.T.A., Lin, C.M., Huang, B.T., Chang, L.F., 1996b. The stoichiometry of carbon, hydrogen, nitrogen, sulfur and oxygen in the particular matter of the western North Pacific marginal seas. Mar. Chem. 54, 179-190.

Chen, C.T.A., Gong, G.C., Wang, S.L., Bychkov, A.S., 1996c. Redfield ratios and regeneration rates of particulate matter in the Sea of Japan as a model of closed system. Geophys. Res. Lett. 23 (14), 1785-1788.

Chen, C.T.A., Wang, S.L., Wang, B.J., Lin, Y.P., Li, F.C., Shu L.M., Chen, L.C., 1997. Preliminary data report of Ocean Researcher 1 cruises 433, 434 and 462, Inst. Mar. Geol. and Chem. Tech. Rep. No. 32, Nat. Sun Yat-sen Univ., 173 pp.

Chen, C.T.A., Wang, S.L., Wang, B.J., Lin, Y.P., Liu, W.H., Li, F.C., Chen, L.C., 1998. Preliminary data report of Ocean Researcher I cruises 508 and Ocean Researcher III 403, Inst. Mar. Geol. and Chem. Tech. Rep. No. 33, Nat. Sun Yat-Sen Univ., 137 pp.

Chu, T.Y., 1972. Oceanographic data of the South China Sea Researcher 1 cruises 1 and 2, Inst. Oceanogr. Special Publication: No. 2, Nat. Taiwan Univ., 74 pp.

Codispoti, L.A., 1995. Is the ocean losing nitrate? Nature 376, 724.

Craig, H., Weiss, R.F., 1970. The GEOSECS 1969 intercalibra- tion station: introduction and hydrographic features, and total $\mathrm{CO}_{2}-\mathrm{O}_{2}$ relationships. J. Geophys. Res. 75, 7641-7647.

Fanning, K.A., Pilson, M.E.Q., 1973. On the spectrophotometric determination of dissolved silica in natural waters. Anal. Chem. 45, 136-141.

Frische, A., Quadfasel, D., 1990. Hydrography of the Sulu Sea. In: Rangin, C., Silver, E., Von Breymann, M.T. (Eds.), Proceedings of the Ocean Drilling Program, Initial Reports, vol 124, Texas A\&M University, College Station, pp. 101-104.

Fujien Oceanological Institute, 1988. A Comprehensive Oceanographic Survey of the Central and Northern Part of the Taiwan Strait. Kexue Pub., Beijing, 423 pp. (in Chinese).

Gong, G.C., Liu, K.K., Liu, C.T., Pai, S.C., 1992. The chemical hydrography of the South China Sea west of Luzon and a comparison with the West Philippine Sea. Terr. Atmos. Oceanic Sci. 3, 587-602.

Han, W.Y., 1995. Marine Chemistry of the Nansha Islands and South China Sea. China Ocean Press, Beijing, 376 pp.

Hong, H.S. (Ed.), 1994. Marine Biogeochemistry Research Papers. Xiamen Univ. Press, Xiamen, China, 283 pp.

Hong, H.S., Dai, M.H., 1994. Biogeochemical studies of biologically important elements in the Taiwan Strait. In: Zhou, D. (Ed.), Oceanology of China Seas, vol. V1, Kluwer Academic Publishing, Boston, pp. 201-212.

INDOPAC, 1978, Data report, Univ. Calif. Scripps Inst. Oceanogr. SID 78-21, 424 pp.

Lai, Z.L., Liu, K.K., 1994. The distribution of carbon, nitrogen and sulfur in surfacial sediments on the continental shelf and slope in northern South China Sea. Acta Oceanogr. Taiwan. 32, 30-44.

Liu, C.T., Liu, R.J., 1988. The deep current in the Bashi Channel. Acta Oceanogr. Taiwan. 20, 107-116.

Liu, Q.Y., Liu, Z.T., Zheng, S.P., Xu, Q.C., Li, W., 1996. The deformation of Kuroshio in the Luzon Strait and its dynamics. J. Ocean Univ. Qingdao 26, 413-420 (in Chinese with English abstract).

Metzger, E.J., Hurlburt, H.E., 1995. Coupled dynamics of the South China Sea, the Sulu Sea and the Pacific Ocean. J. Geophys. Res. 101 (C5), 12331-12352.

Meybeck, M., 1993. C, N, P and S in rivers: from sources to global inputs. In: Wollast, R., Mackenzie, F.T., Chou, L. (Eds.), Interactions of C, N, P, and S Biogeochemical Cycles and Global Change. Springer, Berlin, pp. 163-193.

Middelburg, J.J., Soetaert, K., Herman, P.M.J., Heip, C.H.R., 1996. Denitrification in marine sediments: a model study. Global Biogeochem. Cycle 10, 661-673.

Milliman, J.D., Rutkowski, C.M., Meybeck, M., 1995. River Discharge to the Sea, A Global River Index (GLORI). LOICZ Core Project Office, Netherlands, 125 pp.

Murphy, J., Riley, J.P., 1962. A modified single solution method for the determination of phosphate in natural waters. Anal. Chim. Acta 27, 31-36.

NOAA, 1994a. World Ocean Atlas 1994, V.3: Salinity, NOAA Atlas NESDIS 3, 99 pp.

NOAA, 1994b. World Ocean Atlas 1994, V.1: Nutrients, NOAA Atlas NESDIS 1, $150 \mathrm{pp}$.

Pai, S.-C., Yang, C.-C., Riley, J.P., 1990a. Formation kinetics of 
the pink azo dye in the determination of nitrite in natural waters. Anal. Chim. Acta 232, 345-349.

Pai, S.-C., Yang, C.-C., Riley, J.P., 1990b. Effects of acidity and molybdate concentration on the kinetics of the formation of the phosphoantimonylmolybdenum blue complex. Anal. Chim. Acta 229, 115-120.

Pai, S.-C., Gong, G.-C., Liu, K.-K., 1993. Determination of dissolved oxygen in seawater by direct spectrophotometry of total iodine. Mar. Chem. 41, 343-351.

San Diego-McGlone, M.L., Jacinto, G.S., Dupra, V.C., Narcise, I.S., Padayao, D.O., Velasquez, I.B., 1999. A comparison of nutrient characteristics and primary productivity in the Sulu and South China Sea. Acta Oceanogr. Taiwan. 37, 219-229.

Seitzinger, S.P., Giblin, A.E., 1996. Estimating denitrification in North Atlantic continental shelf sediments. Biogeochemistry 35, 235-260.

Shaw, P.T., Chao, S.Y., Liu, K.K., Pai, S.C., Liu, C.T., 1996. Winter upwelling off Luzon in the northeastern South China Sea. J. Geophys. Res. 101, 16435-16448.

Strickland, J.D.H., Parsons, T.R., 1972. A Practical Handbook of Seawater Analysis. Fisheries Research Board of Canada, Ottawa, Canada, 310 pp.

Su, G.Q., Wang, T.X., 1994. Basic characteristics of modern sedimentation in South China Sea. In: Zhou, D., Liang, Y.B., Zeng, C.K. (Eds.), Oceanology of China Seas, vol. 2, Kluwer Academic Publishing, Boston, pp. 407-418.
Wang, J., 1986. Observation of abyssal flows in the northern South China Sea. Acta Oceanogr. Taiwan. 16, 36-45.

Wang, Y.H., 1991. Marine Atlas of Boshi Sea, Yellow Sea, East China Sea, Chemistry. China Ocean Press, Beijing, 257 pp.

Wang, P.X., 1999. Response of Western Pacific marginal seas to glacial cycles: paleoceanographic and sedimentological features. Mar. Geol. 156, 5-39.

Wang, J., Chen, C.S., 1992. On the distribution of bottom cold waters in Taiwan Strait during summertime. La mer 30, 213-221.

Wang, H.C., Yuan, Y.C., 1997. Calculation of currents in the Taiwan Strait during summertime. Acta Oceanol. Sin. 19, 10-20.

Wollast, R.J., 1998. Evaluation and comparison of the global carbon cycle in the coastal zone and in the open ocean. In: Brink, K.H., Robinson, A.R. (Eds.), The Sea, vol. 10, Wiley, New York, pp. 213-252.

Wyrtki, K., 1961. Physical oceanography of the southeast Asian waters. Scientific results of marine investigations of the South China Sea and the Gulf of Thailand, Scripps Institution of Oceanography, La Jolla, CA, NAGA report, vol. 2, 195 pp.

Zhang, J., 1996. Nutrient elements in large Chinese estuaries. Cont. Shelf Res. 16, 1023-1045.

Zhang, Y.K., Wang, X.C., Zhang, Q.L., Wang, C.M., 1991. Bottom current in Taiwan Strait. Oceanol. Limnol. Sin. 22, 124-131 (in Chinese with English abstract). 